\title{
Corneal Repair and Regeneration: Current Concepts and Future Directions
}

\begin{abstract}
Mohammadmahdi Mobaraki ${ }^{1}$, Reza Abbasi ${ }^{1}$, Sajjad Omidian Vandchali ${ }^{1}$, Maryam Ghaffari ${ }^{1}$, Fathollah Moztarzadeh ${ }^{1}$ and Masoud Mozafari ${ }^{2 *}$
\end{abstract}

${ }^{1}$ Biomaterials Group, Department of Biomedical Engineering, Amirkabir University of Technology, Tehran, Iran, ${ }^{2}$ Department of Tissue Engineering and Regenerative Medicine, Faculty of Advanced Technologies in Medicine, Iran University of Medical Sciences, Tehran, Iran

The cornea is a unique tissue and the most powerful focusing element of the eye, known as a window to the eye. Infectious or non-infectious diseases might cause severe visual impairments that need medical intervention to restore patients' vision. The most prominent characteristics of the cornea are its mechanical strength and transparency, which are indeed the most important criteria considerations when reconstructing the injured cornea. Corneal strength comes from about 200 collagen lamellae which criss-cross the cornea in different directions and comprise nearly $90 \%$ of the thickness of the cornea. Regarding corneal transparency, the specific characteristics of the cornea include its immune and angiogenic privilege besides its limbus zone. On the other hand, angiogenic privilege involves several active cascades in which anti-angiogenic factors are produced to compensate for the enhanced production of proangiogenic factors after wound healing. Limbus of the cornea forms a border between the corneal and conjunctival epithelium, and its limbal stem cells (LSCS) are essential in maintenance and repair of the adult cornea through its support of corneal epithelial tissue repair and regeneration. As a result, the main factors which threaten the corneal clarity are inflammatory reactions, neovascularization, and limbal deficiency. In fact, the influx of inflammatory cells causes scar formation and destruction of the limbus zone. Current studies about wound healing treatment focus on corneal characteristics such as the immune response, angiogenesis, and cell signaling. In this review, studied topics related to wound healing and new approaches in cornea regeneration, which are mostly related to the criteria mentioned above, will be discussed.

\footnotetext{
Keywords: cornea, tissue engineering, wound healing, regenerative medicine, biomaterials, immune privilege, angiogenesis, limbus
}

\section{INTRODUCTION}

Diseases affecting the cornea can be either infectious or non-infectious, and both may cause severe visual impairments requiring intervention. Trachoma, onchocerciasis, corneal ulceration, corneal dystrophies, and xerophthalmia are some of the major causes of blindness worldwide (Sommer, 1982). However, the prevalence and epidemiology of corneal diseases varies from region to region. 
From the use of traditional eye medicines (which is now considered a significant risk factor for corneal ulceration) to collagen cross-linking, which has recently been approved by the US FDA to strengthen the cornea, the ultimate goal in corneal treatment is to employ minimally invasive procedures that can restore or preserve vision (Jeng et al., 2016). Stimulating the body's repair mechanisms is now considered to be the gold standard for the functional healing of damaged tissues and organs (Khadem et al., 2000, 2004; Zarrintaj et al., 2017). This approach is typified by corneal transplantation and tissue engineering.

The most striking advance in the medical treatment of corneal diseases over recent decades has been corneal transplantation and, nowadays, the cornea is the most commonly transplanted tissue worldwide. Corneal transplantations are divided into two main categories based upon the amount of surgically replaced tissue. In penetrating keratoplasty, the entire cornea is replaced with a donor tissue. However, in a newer procedure called lamellar keratoplasty, only the damaged layers are replaced with a donor graft, and the healthy part of the cornea is left intact. In lamellar keratoplasty, the integrity of the cornea and the surrounding tissues are preserved; as a result, better visual improvement is usually achieved. Unfortunately, there are sometimes poor outcomes because of graft rejection or late graft failure. Furthermore, according to a World Health Organization (WHO) report, 15-20\% of patients who need corneal transplantation remain untreated because of the shortage of corneal donors (Whitcher et al., 2001). Over the last few decades, the shortage of donor tissues, beside fears of transmissible diseases, has accelerated studies on finding an alternative treatment to transplantation, and an artificial cornea or keratoprosthesis has been suggested as an option. Historically, Guillaume Pellier de Quengsy Jr. was the first person who proposed a thin silver-rimmed convex glass disc as an artificial cornea, as long ago as 1789 (Mannis and Mannis, 1999). At that time, the first priority was to choose transparent and non-irritating materials, but as time went by other researchers concentrated on designing an artificial cornea which was able to promote better incorporation with the host tissue. Glass and quartz were the choices for the transparent part of the prosthesis and natural polymers like gutta-percha and casein were added to the artificial cornea design. Later, gold rings and platinum rings were used to achieve better incorporation with the host cornea. Further studies on artificial corneas resulted in replacing glass and quartz with lighter materials. At the beginning of the twentieth century, attention was diverted from artificial corneas to transplantation of donor corneal after the first successful keratoplasty (Zirm, 1989). Nevertheless, studies on artificial corneas have never ceased. Today there are four types of keratoprostheses, which are in commercial use. In the following section, these keratoprostheses will be further discussed. Despite some clinical success in using artificial corneas, the host rejection is still relatively high. The presence of corneal epithelial stem cells, which are located in the basal epithelial layer of the corneal limbus (the border between the cornea and the sclera), has given some hope for better healing and integration. Therefore, many researchers have focused on employing new biomaterials to mimic the corneal architecture, which would allow better corneal self-repair. This review will discuss recent advances in repairing damaged corneas, focusing on new concepts and biomaterials (Figure 1; Muijzer et al., 2019).

\section{CORNEA STRUCTURE AND TRANSPARENCY}

The human cornea is a unique tissue with two critical functions. On the one hand, the cornea forms the anterior portion of the outer casing of the eye and protects the inner portion of the eye from the external environment. On the other hand, it is the single most powerful focusing element of the eye. It provides about $80 \%$ refractive power of the eye and it is roughly twice as powerful as the lens. Because of these functions, the cornea is both mechanically strong and transparent. Its strength comes from about 200 collagen lamellae, which crisscross the cornea in different directions. This collagen-rich layer of the cornea comprises nearly $90 \%$ of the thickness of the cornea and is called the "stroma proper layer." In fact, the human cornea is composed of five primary layers-epithelium, Bowman's layer, stroma proper, Descemet's membrane, and endothelium. This hierarchical structure can be described as a fibril-reinforced laminate biocomposite, which provides an excellent compromise between stiffness, strength, toughness, and extensibility. In Figure 2 the hierarchical structure of the cornea, with macroscopic, microscopic, and nanoscopic features, is shown (Kaufman et al., 2011). As noted earlier, the cornea is transparent; however, the hierarchical structure and the presence of interfaces between the different layers, each with its own index of refraction, seem to be in contradiction with its clarity. There have been lots of studies attempting to explain the transparency of the cornea. The first explanations in the nineteenth century emphasized the homogeneity of the cornea and the fact that the collagen fibrils had the same refractive index. After about a century, Dr. Maurice (1957) tried to explain the optical structure of the cornea considering its geometric form, dimensions and the refractive indices of its components. He suggested that the scattered waves from collagen fibrils interfered with each other in such a way that they canceled out each other in all directions, except the forward direction. Meanwhile, Miller and Benedek (1973) in 1973 showed that the gaps between the interfaces were smaller than one-half the wavelength of visible light; and as a result, the cornea is crystal clear. Recently Meek and Knupp (2015) have reviewed the current state of knowledge about the corneal architecture and its optical transparency. These authors outlined the general basis and molecular mechanisms of corneal transparency. Maurice's suggestion regarding the interaction of the incoming electromagnetic waves with the collagen fibrils was proved to be correct by new imaging technologies (Quantock et al., 2015).

\section{CORNEAL REPLACEMENTS}

Boston Keratoprosthesis (B-KPro), Osteo-OdontoKeratoprosthesis (OOKP), AlphaCor, and the KeraKlear Artificial Cornea are the four types of keratoprostheses which 


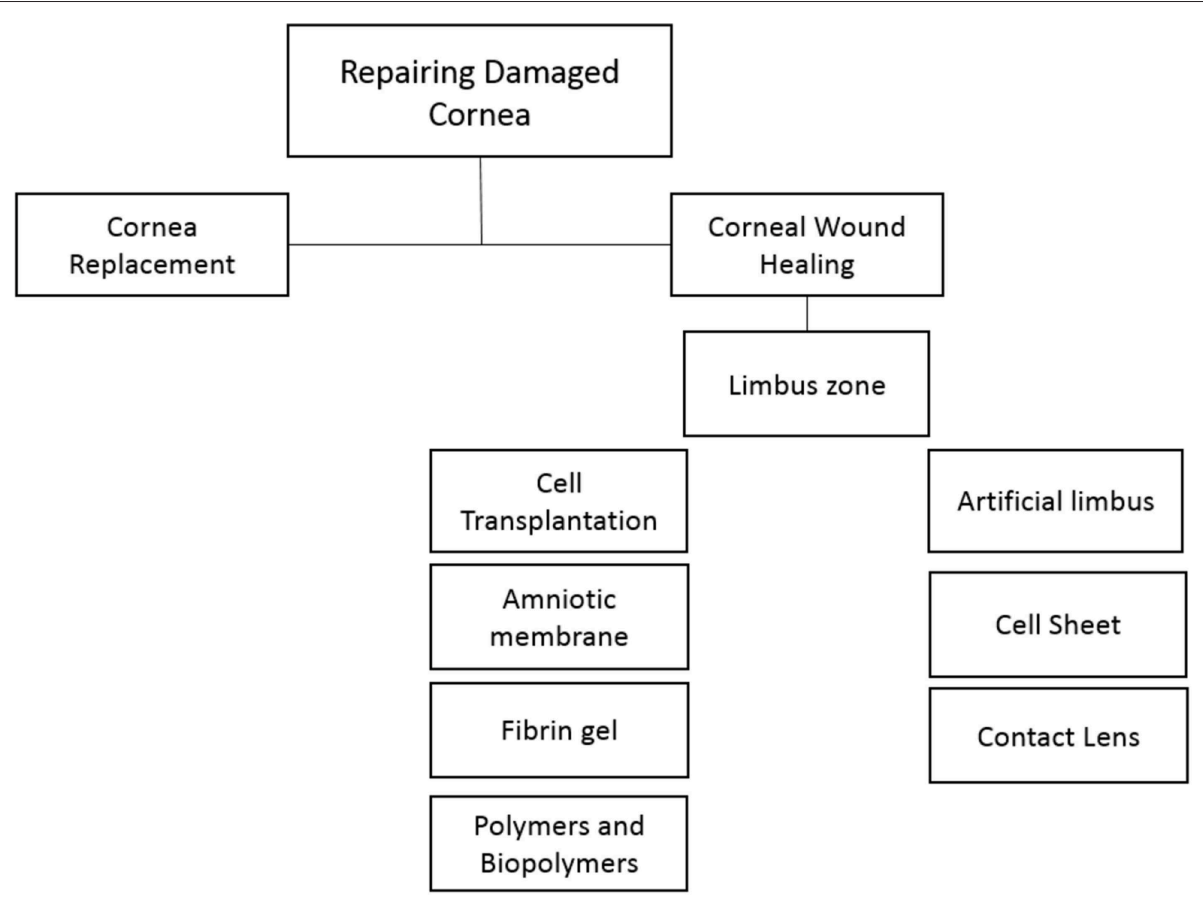

FIGURE 1 | Current strategies for the repair and regeneration of damaged cornea.

have, so far, been commercialized. Over the last decade, implantation of artificial corneas has been dramatically increased. For instance, fewer than 50 units of B-KPro were implanted before 2002, while more than 9,000 implantations were carried out in 2014. In this section, recent advances in the design of artificial corneas will be discussed with regard to the type of materials employed.

The B-KPro is the most widely implanted artificial cornea and was developed at the Massachusetts Eye and Ear Infirmary. There are two types of B-KPro each with different indications. The BKPro type I is commonly used in patients with a non-cicatrizing disease such as repeated allograft failure, corneal opacity with extensive neovascularization, aniridia, trauma, etc. In contrast, $\mathrm{B}$-KPro type II is used in cicatrizing diseases and severe dry eye conditions, such as severe autoimmune ocular diseases. Both types of B-KPro have similar compartments but are different in some details. They have a front plate and a back plate, which act to sandwich a fresh donor cornea; a titanium locking-ring is used to secure the plates. Medical grade polymethyl methacrylate (PMMA) with the ability to block UVA/UVB is used for the front and back plates. The idea of using PMMA was conceived due to its ability to induce only minimal inflammatory responses in the eye (Griffith et al., 2016). PMMA is a transparent thermoplastic polymer, also known as acrylic glass, which can be modified to achieve desired mechanical properties, like toughness and stiffness. On the other hand, modifying the PMMA polymer with nano-dimensional $\mathrm{TiO} 2, \mathrm{SiO} 2, \mathrm{ZnO}, \mathrm{ZrO} 2, \mathrm{Al} 2 \mathrm{O} 3, \mathrm{CNT}$, and graphene has been investigated for electromagnetic shielding, thermal insulation, antiglare resistance, scratch resistance, and also resistance against UV radiation (Pandey et al., 2010; Cano et al., 2013; Soumya et al., 2014). The apparent success of PMMA in keratoprostheses has been plagued by numerous complications like tissue necrosis, retroprosthetic membrane formation, vitreous opacities, etc. The main reasons for these shortcomings include poor adhesion between the PMMA and the host corneal collagen at the PMMA-host interface and fibrous membrane formation due to fibroblast attachment onto the inner surface of PMMA. Therefore, there have been ongoing research efforts to overcome these drawbacks. In the first attempts, PMMA surfaces were modified with polyethylene glycol (PEG) or extracellular matrix molecules to block cell adhesion (Kim et al., 2001; Aucoin et al., 2002). The results were promising in terms of preserving the inner surface of PMMA but, at the external PMMA-host interface, the reduction in cell attachment resulted in endophthalmitis and extrusion of the implant. Endophthalmitis is an internal inflammation of the eye, which is a possible complication of B-KPro, arising because of inadequate integration of PMMA with the host corneal tissue allowing penetration of microorganisms. Suggested ways to reduce this drawback include using of daily antibiotics and modifying the BKPro surface. Using antibiotics is out of the scope of this paper, so only surface modification of PMMA will be discussed.

Surface modifications of PMMA have been studied using two approaches. One of them focuses on improving cell attachment at the PMMA-corneal tissue interface to prevent the penetration of microorganisms into the internal part of the eye. In this context, Patel et al. (2006) studied the region-specific control of cell adhesion by grafting di-amino-PEG onto the surface of PMMA which could be used to improve cell adhesion and spatially control cell attachment onto the PMMA. Recently the 


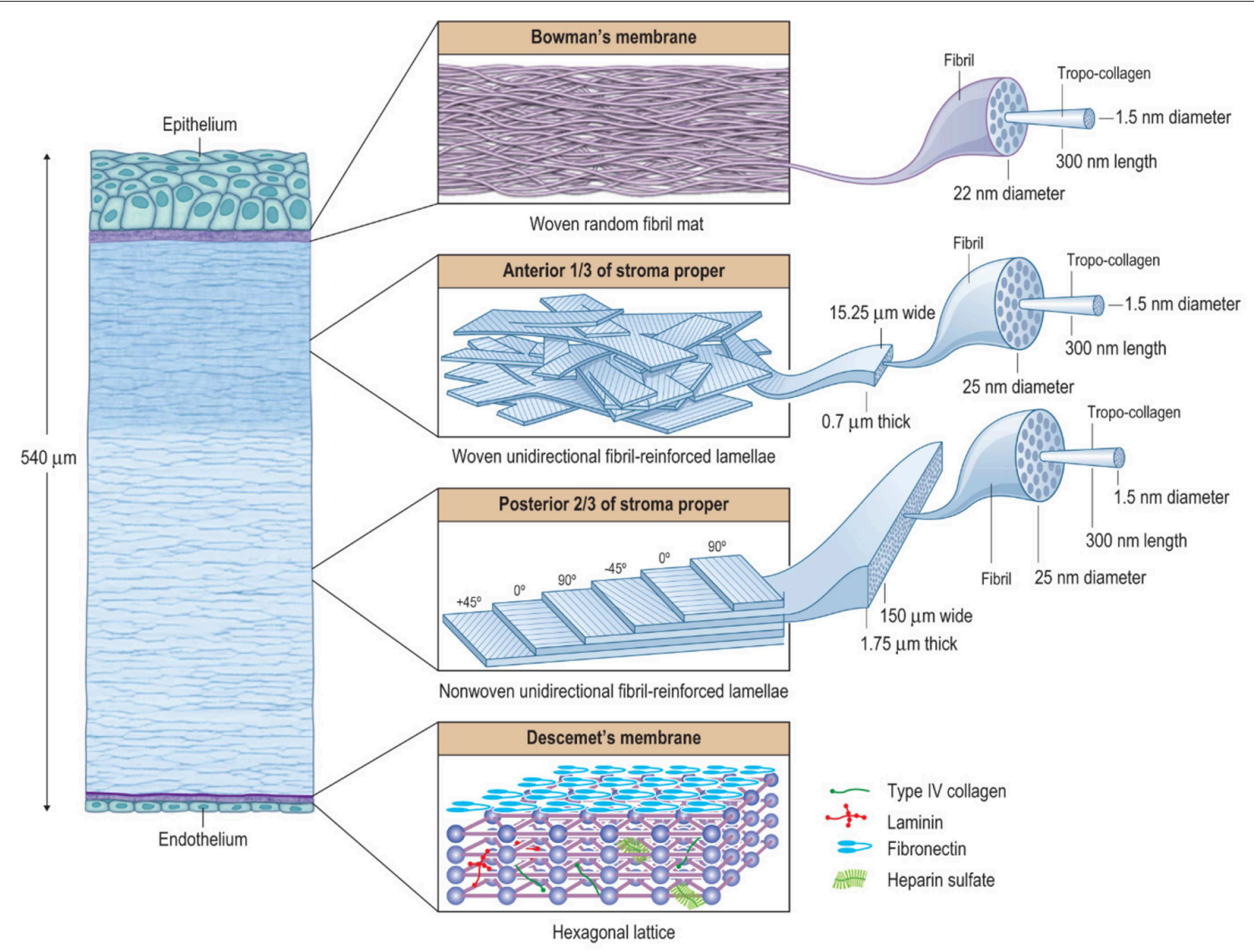

FIGURE 2 | The hierarchical structure of the cornea showing that it is basically composed of three composite regions. A fourth composite region, Descemet's membrane, is included for completion. The macroscopic, microscopic, and nanoscopic features are emphasized (from left to right) to help illustrate the various interactions between the tissue components. Bowman's layer is essentially a random fibril, woven-mat composite, which maximizes multi-axial stiffness and strength. The underlying anterior third of the stroma proper is a lamellar interwoven fabric composed of unidirectionally (UD) fibril-reinforced lamellae. This architectural hierarchy is more rigid against z-axis deformations compared to non-woven UD-laminates. In the human body, the corneal structure is most similar to that of the pericardium, which serves to mechanically prevent the formation of aneurysms in the heart. The posterior two-thirds of the stroma is essentially a non-woven, UD-fibril-reinforced lamellar composite, which maximizes longitudinal $\mathrm{x}$ - and $\mathrm{y}$-axis stiffness and strength, but has only weak transverse $z$-axis stiffness and strength. In the human body, its structure is most similar to that of the annulus fibrosis of the intervertebral disk, which functions efficiently as a cushioning mechanism for the spine, but is prone to chronic biomechanical failure. The UD-orientation of collagen fibrils in each lamella is vital because this arrangement prevents fibril undulation and thus maximizes the initial axial tensile strength of each fibril. Descemet's membrane forms a hexagonal lattice. Taken together these composite-like regions are responsible for the overall stiffness, strength, extensibility, and toughness of the cornea. They also help explain how the cornea behaves biomechanically after surgery, disease, or injury.

Reprinted with permission (Kaufman et al., 2011).

stability and biocompatibility of poly (2-hydroxyl methacrylate)polymethyl methacrylate (PHEMA-PMMA) has been studied and has shown promising optical transparency, flexibility, and good mechanical properties. Nevertheless, its stability and biocompatibility still need further research (Hwang and Kim, 2016). The second approach is to fabricate a PMMA polymer with antibacterial properties. Examples of these antibacterial coatings are titanium dioxide (TiO2) (Riau et al., 2016) and silver nanocluster (Baino et al., 2016). For instance, SalvadorCulla et al. showed that a $\mathrm{TiO} 2$ coating on PMMA enhanced keratocyte cell integration and attachment, while at the same time demonstrated antibacterial properties (Salvador-Culla et al., 2016). In another attempt, researchers at the University of California, Irvine (UC Irvine) mimicked the surface of insect wings to make an antibacterial PMMA for using in an artificial cornea (Kowalski, 2016).

In the presence of severe ocular surface inflammation like chemical burns, end-stage Stevens-Johnson syndrome, ocular cicatricial pemphigoid, multiple failed penetrating keratoplasties, and trachoma, the use of the Osteo-Odonto-Keratoprosthesis (OOKP) is an alternative approach. Multiple efforts in using more biologically compatible substances resulted in the introduction of OOKP in 1963 by Strampelli (Han et al., 2015b). In this kind of artificial cornea, an autologous tooth was cut horizontally (OOKP) or longitudinally (MOOKP) to allow an optical cylinder made of PMMA to be introduced inside it. MOOKP is a modified OOKP introduced by Falcinelli et al. (1987). Tibia KPro is another type of biological keratoprosthesis 
in which a fragment of the autologous tibia was used to allow anatomical retention for an extended period of time. The biological parts of OOKP and MOOKP are known as a "keratoprosthesis skirt" and various studies have suggested that the use of living materials results in lowering the risk of extrusion and infection (Falcinelli et al., 2005). Beside the biological parts of OOKP and MOOKP, two other types of synthetic materials are used in these implants. These are (a) the transparent material, which is used in the optical cylinder, and (b) the adhesive, which is used to bond the optical cylinder to the biological parts. PMMA is a gold standard transparent, water-resistant, and durable material for the optical cylinder. However, as mentioned before, there are ongoing studies toward improving its characteristics. Acrylic bone cement is a standard dental adhesive, which is commonly used, and its suitability has never been seriously challenged. Yet, studies on other dental adhesives like glass ionomer and universal resin cement have been conducted (Weisshuhn et al., 2014; Alarcon et al., 2016).

In comparison with B-KPo, MOOKP is cheaper and does not require a viable donor cornea. However, there are some obstacles and controversial issues related to the use of OOKP and MOOKP. For instance, two fundamental surgical procedures need to be performed to implant the biological keratoprosthesis, and there is a 3-month interval between these procedures. This requirement complicates the surgery and reduces patient satisfaction. As a result, in the last decade, research on OOKP and MOOKP has focused on replacing the biological skirt with a synthetic skirt that enables it to biointegrate with the surrounding corneal tissue. Synthetic skirts have shown better mechanical biocompatibility with the sclera, in addition to more comfortable fabrication and better handling during the surgery. AlphaCor is one of the commercially available artificial corneas with a synthetic skirt. This kind of keratoprosthesis has been studied and developed in the Lion Eye Institute of Western Australia since 1989. AlphaCor is a one-piece device with two concentric regions that made from poly-(2-hydroxyethylmethacrylate) (PHEMA). The central core of the device is a transparent PHEMA cylinder, and the skirt is a porous PHEMA material to improve biointegration with the surrounding corneal stromal tissue. Nevertheless, the rejection rates of the synthetic skirt is much higher than the biological skirts discussed above (Polisetti et al., 2013). Thus, improving the biointegration of the synthetic skirt is an important objective in recent studies. In this regard, Pino et al. (2008) attempted to increase the bioactivity of various synthetic polymers using biomimetic coatings. They suggested that growing a bioactive apatite layer on the surface of the polymers would provide well in vivo biointegration. Another approach to enhancing the bioactivity of the skirt is to modify the surface of the skirt with extracellular matrix proteins like fibronectin, laminin, and collagen (Xie et al., 1997). Moreover, replacing the polymers with bioactive materials like bioglass has also been investigated (Laattala et al., 2011). Accordingly, Huhtinen et al. (2013) replaced the polymeric skirt of the keratoprosthesis with bioactive glass. They claimed that the porous bioglass had a capacity to induce and support tissue ingrowth, resulting in better biointegration. Similar investigations using other innovative materials have been proposed by other research groups. Recently, Tan et al. (2015) assessed the potential of two-dimensional graphene film and 3D graphene foam as a next-generation biomaterial for the synthetic keratoprosthesis skirt.

Considering the advantages and disadvantages of the three commercial keratoprosthesis which have been discussed above, KeraMed Inc. (Sunnyvale, California) has introduced a newer design to address the limitations of previous keratoprostheses while retaining their advantages. KeraKlear Artificial Cornea is a one-piece keratoprosthesis without any need for a donor cornea. Moreover, using only acrylic material allows KeraKlear to be foldable and injectable. However, its implantation is technically challenging, and further investigations are needed to overcome these challenges (Pineda, 2015). Besides, KeraKlear is a new product, and more clinical evaluation is necessary to ensure its safety and efficacy. To summarize the above discussions, the keratoprostheses are compared with two other recently introduced artificial corneas in Table 1 and Figure 3.

\section{CORNEAL WOUND HEALING}

Corneal wound healing, like wound healing in general, is a complex and dynamic process which is divided into four phases: the hemostasis, inflammation, cell proliferation, and remodeling phases. In fact, wound healing involves the interaction of various different cell lineages and a choreographed series of cellular events resulting in the replacement of the missing tissue or cellular structures. The cornea has special characteristics, which are important to consider in choosing a treatment strategy for wound healing. The most prominent characteristics of the cornea include its limbus zone, its lack of blood vessels, and its immune privilege (see Figure 4). As a result, current studies in corneal wound healing treatment have focused on a corneal characteristic like an immune response, avoiding angiogenesis and modulating cell signaling. In this section, topics related to angiogenesis and immune privilege, such as blocking immune signaling pathways, exosomes, biopolymers, growth factors, and use of amniotic membrane, will be discussed. New approaches to corneal wound healing related to the limbus zone will be reviewed in the following section (Simpson et al., 2019).

\section{Corneal Immune Privilege and Avoidance of Angiogenesis}

Generally, the transparency and avascularity of the cornea are essential for proper vision. The main factors, which are threatening the corneal clarity are inflammatory reactions, neovascularization, and limbal deficiency. As a result, avoiding angiogenesis, maintaining immune privilege, and supporting the limbus zone are strategies that have been investigated to combat processes that endanger corneal transparency. Immune privilege describes the natural lack of inflammation in the cornea, but when wound healing is taking place, the immune response needs to be modulated and limited. The influx of inflammatory cells causes scar formation and destruction of the limbus zone. Since there is a naturally enhanced production of proangiogenic factors during wound healing (Cursiefen, 2007; Ellenberg et al., 2010), 
TABLE 1 | Comparison of major clinically used keratorostheses.

\begin{tabular}{|c|c|c|c|c|c|}
\hline & Core material & Skirt material & Surgery stages & Further studies on & References \\
\hline B-KPro & Donor cornea with PMMA & Titanium & 1 stages & $\begin{array}{l}\text { Improve adhesion between the cornea and } \\
\text { the prosthesis }\end{array}$ & Lee et al., 2017 \\
\hline OOKP & PMMA & Tooth, Tibia & 2-3 stages & Replace the biological part & Hille, 2018 \\
\hline Alphacor & PHEMA & Porous PHEMA & 2 stages & $\begin{array}{l}\text { Improve adhesion between the cornea and } \\
\text { the prosthesis }\end{array}$ & Jirásková et al., 2011 \\
\hline KeraKlear $^{\circledR}$ & $\begin{array}{l}\text { Hydrophilic acrylic } \\
\text { polymer }\end{array}$ & Hydrophilic acrylic material & 1 stages & $\begin{array}{l}\text { Improve adhesion between the cornea and } \\
\text { the prosthesis (biointegration) }\end{array}$ & Pineda, 2015 \\
\hline $\mathrm{MICOF}^{\star}$ & PMMA & Titanium & 2 stages & $\begin{array}{l}\text { Improve adhesion between the cornea and } \\
\text { the prosthesis (biointegration) }\end{array}$ & $\begin{array}{l}\text { Wang et al., 2015; Ma } \\
\text { et al., } 2017\end{array}$ \\
\hline $\begin{array}{l}\text { Miro } \\
\text { Cornea }{ }^{\circledR}\end{array}$ & $\begin{array}{l}\text { Hydrophobic acrylic } \\
\text { polymer }\end{array}$ & $\begin{array}{l}\text { Hydrophobic acrylic } \\
\text { polymer }\end{array}$ & 1 stages & $\begin{array}{l}\text { Improve adhesion between the cornea and } \\
\text { the prosthesis (biointegration) }\end{array}$ & Schrage et al., 2014 \\
\hline
\end{tabular}

${ }^{\star}$ Moscow eye microsurgery complex in Russia.
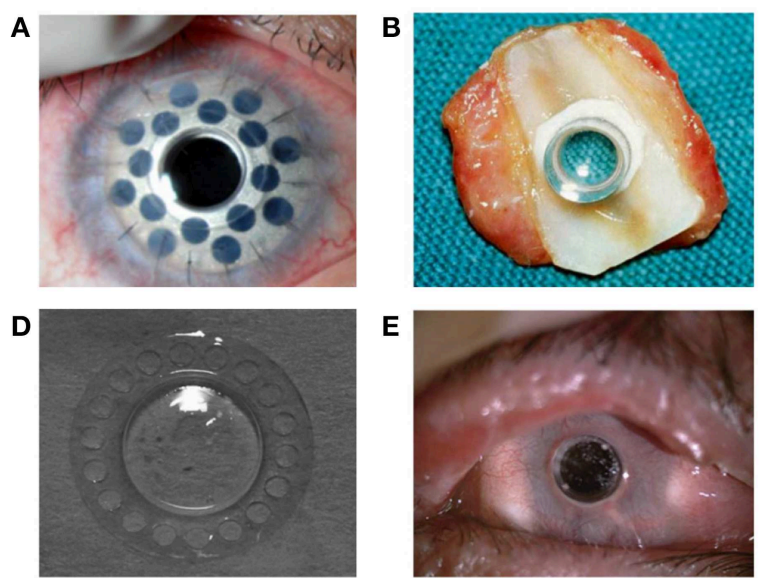

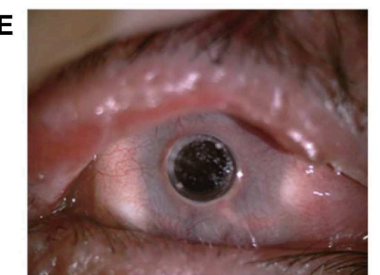

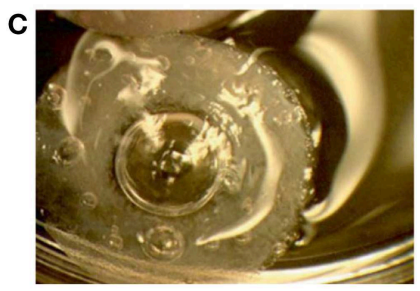

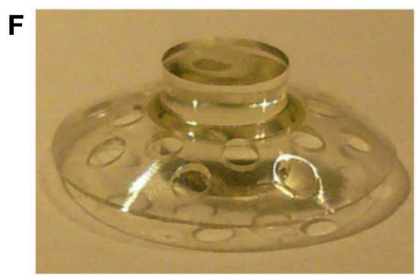

FIGURE 3 | (A) Boston keratoprosthesis Type I with titanium back plate. Reprinted with permission from Dohlman et al. (2014). (B) Osteodental-acrylic complex with polymethyl methacrylate optical cylinder. (C) Both core and skirt are shown in this picture. The skirt is white due to collagen incorporated in the pores. The clear ring between the center and the skirt shows interdigitation between the two components. (D) Front profile of the KeraKlear keratoprosthesis demonstrating the 18-hole peripheral design with $4.0 \mathrm{~mm}$ central optic. Reprinted with permission from Cortina and De La Cruz (2015). (E) MICOF KPro is composed of two parts: a titanium frame and a central PMMA cylinder. Reprinted with permission from Huang et al. (2012). (F) MiroCornea UR keratoprosthesis. Reprinted with permission from Duncker et al. (2014).

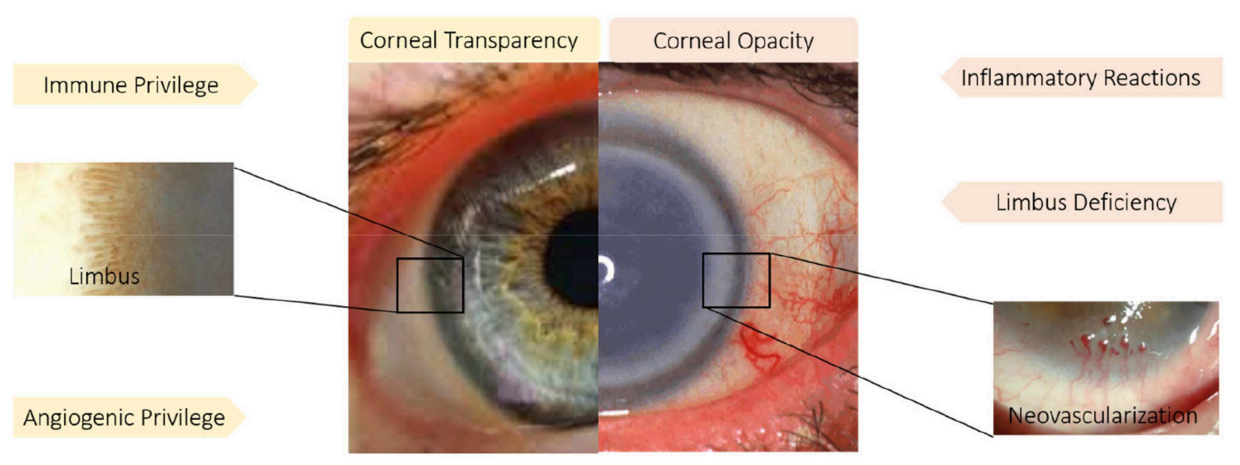

FIGURE 4 | Immune and angiogenic privilege besides limbus structure play a pivotal role in corneal transparency. While inflammatory reaction, neovascularization and limbus deficiency endanger corneal transparency. Reprinted with permission from Ellenberg et al. (2010) and Haagdorens et al. (2016). 
actions need to be taken to restrict the undesirable growth of blood vessels into the cornea. In the following section, recent studies on this issue will be discussed.

\section{Blocking Immune Signaling Pathways}

Aggressive inflammatory responses following ocular injuries often tend to impair corneal re-epithelization which results in loss of corneal transparency and impairment of vision. Immune responses in cornea have been studied extensively in the context of the role of epithelial cells and immune signaling pathways that are involved. One of the most recognized immune signaling pathways is the inflammasome pathway which is activated in the wound healing response (Schroder and Tschopp, 2010). Recently, Bian et al. described a novel inflammasome signaling pathway which is activated in damaged corneal epithelial cells. They also suggested that blocking this pathway could result in a reduced inflammation which would improve the wound healing and the corneal transparency (Bian et al., 2017).

\section{Exosome}

Corneal epithelial cells (besides their ability to renew themselves) play a pivotal role in wound healing by carrying out intercellular signaling and communication with stromal cells. Exosomes are cell-derived nanoscale vesicles containing bioactive molecules, which mediate intracellular signaling (Cocucci et al., 2009; Han et al., 2015a). Han et al. have focused on the role of exosomes in corneal wound healing. In their recent study (Han et al., 2017), they characterized corneal epithelial cell-derived exosomes. Their findings indicate the role of exosomes derived from corneal epithelial cells in mediating the intercellular communication between the epithelium and the stroma during corneal wound healing. These exosomes may serve as a therapeutic strategy for the corneal repair.

\section{Biopolymers}

Common treatments for corneal epithelial defects include artificial tears and lubricants which reduce the mechanical stress and inflammatory cytokines. Inhibiting the inflammatory responses may result in the acceleration of corneal wound healing (Zarrintaj et al., 2018d). Inasmuch as biopolymers have shown promising results in tissue engineering and wound healing, their deployment in corneal wound healing has attracted lots of attention (Gholipourmalekabadi et al., 2018; Zarrintaj et al., 2018c). Chitosan, hyaluronic acid, silk fibroin, and polyarginine are among the most studied biopolymers for corneal wound healing. Chitosan and its derivatives have a large number of applications in the human body in various forms, such as scaffolds, drug carriers, and wound dressings (Dai et al., 2011; St. Denis et al., 2012; Oryan and Sahvieh, 2017; Sigroha and Khatkar, 2017). In regard to corneal wound healing, Cui et al. (2017) recently have reported a mechanism by which chitosan could promote corneal wound healing. Their findings showed that the chitosan-stimulated epithelial wound healing was partially mediated through the activation of the extracellular signal-regulated kinase (ERK) pathway. ERK signaling plays a pivotal role in cell proliferation, migration, and differentiation. Chitosan and its derivatives have also been studied as a drug carrier in ocular wound healing (Schmidl et al., 2017; Rahmati and Mozafari, 2019a). Fischak et al. (2017) studied the effects of chitosan-N-acetylcysteine (C-NAC), a new biopolymer, on corneal wound healing. The results showed a faster wound healing due to the specific chemical and biological properties of C-NAC. Other chitosan compositions which have been investigated for corneal wound healing are chitosan-based hydrogels. These hydrogels may either serve as drug carriers (Tsai et al., 2016) or as tissue adhesive materials for hemostasis or wound healing (Deng et al., 2010; Lih et al., 2012; Wicklein et al., 2019).

Hyaluronic acid is one of the abundant polysaccharides in the human body and plays a significant role in corneal wound healing. In vitro and in vivo studies have confirmed the ability of hyaluronic acid to promote wound healing (Neuman et al., 2015). Zhong et al. (2016) studied the mechanism by which exogenous hyaluronic acid promotes corneal wound healing. They studied the expression level of cytokines like Cluster of differentiation (CD44), interferon (IFN), interleukin 1 beta (IL-1 $\beta$ ), and matrix metallopeptidase 9 (MMP-9). Hyaluronic acid down-regulates the expression of inflammatory cytokines and up-regulates the expression of anti-inflammatory cytokines associated with the tissue repair and healing. Though, despite the confirmed effects of hyaluronic acid on promoting corneal wound healing, Gronkiewicz et al. (2017) reported that the topical addition of hyaluronic acid, in combination with standard medical management of corneal ulcers, did not accelerate wound healing.

Fibroin is an insoluble protein derived from the fibers of silk. Hydrophobic domains in the primary sequence of amino acids in fibroin generally result in this protein adopting a $\beta$ sheet structure (Vepari and Kaplan, 2007; Mohammadi et al., 2017; Rahmati and Mozafari, 2018). Lui et al. studied fibroin as a $2 \mathrm{D}$ and $3 \mathrm{D}$-scaffold for corneal stromal engineering applications (Liu et al., 2012) and as a carrier for exogenous application of corneal epithelial cell sheets (Lawrence et al., 2009). Recently, Abdel-Naby et al. (2017) evaluated the influence of fibroin on epithelial cell migration, proliferation, and adhesion. Their results indicated that fibroin might directly enhance wound healing by both stimulating epithelial proliferation and positively impacting the cell migration rate.

Polyarginine is a short cationic polypeptide, which can translocate through cell membranes; as a result, it has attracted much attention as a drug carrier. Some studies have shown that the presence of guanidinium moieties in the backbone of polyarginine, which interacts with anionic groups on the cell membrane through hydrogen bonds and hydrophobic forces, results in the cell-penetrating property of polyarginine (Takechi et al., 2012). Studies of polyarginine as a nanocarrier have significantly increased in recent years, and it has emerged as a new strategy to accelerate wound healing (GonzalezParedes et al., 2017). Reimondez-Troitiño et al. (2016) designed and evaluated polyarginine nanocapsules to improve corneal wound healing. Their findings showed that polyarginine had an intrinsic capacity to promote corneal wound healing through the transforming growth factor beta /SMAD (TGF- $\beta / S M A D$ ) signaling pathway. 


\section{Amniotic Membrane (AM)}

Both fresh and preserved human amniotic membranes have been investigated as naturally occurring biomaterials in tissue reconstruction, especially for the ocular surface. AM is one of the thickest basement membranes that exists in the human body, with the ability to promote epithelial cell healing, besides inhibiting fibroblast proliferation and myofibroblast differentiation. In addition, it contains several anti-angiogenic, anti-inflammatory, and neurotrophic factors (Ramachandran et al., 2019). At present, AM transplantation has been used for various indications including repairing persistent epithelial defects and treating corneal ulceration, limbal stem cell deficiency, acute Stevens Johnson Syndrome (SJS), chemical and thermal burns, infectious keratitis, and after refractive surgery (St. Denis et al., 2012; Manolova et al., 2017; Prabhasawat, 2017; Westekemper et al., 2017). Despite the fact that during the last decades, AM transplantation has been a gold standard for the treatment of a variety of ocular surface diseases, AM transplantation still has several disadvantages. Therefore, multiple efforts have been made to address these downsides. One of the disadvantages is related to the surgical procedure that has several problems. The precise conditions, under which the AM is prepared, affects its biomedical applications (Islam et al., 2018). Wu et al. (2017) analyzed the effect of two different methods of preparations of AM on human corneal epithelial cell (HCEC) viability, migration, and proliferation in vitro. Their study showed that biochemical factors (Keratinocyte growth factor (KGF), Fibroblast growth factor-basic (FGFb), Hepatocyte growth factor (HGF), and TGF- $\beta 1$ ) released from the AM preparation had a complex, possibly non-linear effects, on HCECs. In another study Ogawa et al. identified an active matrix component [Heavy chain-hyaluronan/pentraxin3 (HCHA/PTX3)] that was shown to exert the anti-inflammatory and anti-scarring effects of AM. Their studies revealed that subcutaneous and subconjunctival injection of HC-HA/PTX3 might be a novel approach in the treatment of ocular disease (He et al., 2017a; Ogawa et al., 2017). Recently, this group developed eye drops containing morselized and cryopreserved AM, and also an umbilical cord preparation to understand their therapeutic potential in promoting corneal re-epithelization and restoring the regularity of the corneal surface (Tighe et al., 2017).

\section{Pharmaceutical Agents}

Pathological angiogenesis that occurs in the proliferative phase of corneal wound healing leads to a reduced corneal transparency and loss of vision via lipid deposition and scar formation. Neovascularization is closely related to the angiogenic signaling pathway, which is initiated by the infiltration into the cornea of large numbers of neutrophils and macrophages. Several studies have shown the potential benefit of using anti-angiogenic agents to inhibit corneal neovascularization. Different methods have been suggested to inhibit the development of corneal neovascularization like genetic ablation of the chemokine receptor CCR2 (Ambati et al., 2003) and to control proangiogenic factors (Baradaran-Rafii et al., 2017). Zerumbone is a cyclic terpene which is isolated from the rhizomes of wild ginger. Presently, zerumbone has been extensively studied for its antitumor, anti-inflammatory, antimicrobial, and antiangiogenic activities (Rahman et al., 2014). Kim et al. (2017b) recently examined the effects of zerumbone on chemokinerelated macrophage infiltration in the corneal wound healing process. Their results indicated that zerumbone prevented angiogenesis and fibrosis through the inhibition of inflammatory cells activation.

Anti-inflammatory agents like corticosteroids have long been topically applied for the treatment of ocular inflammation. However, they show a low therapeutic efficacy in the treatment of neovascularization, because of their poor corneal permeability, and lack of bioavailability (Mozafari, 2014). Various drug delivery systems like viscous solutions, nanoparticles, carbon nanotubes, micelles, liposomes, and hydrogels have been proposed to overcome the aforementioned problems (Karimi et al., 2015a,b, 2016a,b,c; Weng et al., 2017). Recently, Nagai et al. (2017) designed a new type of solid nanoparticles based on zirconia beads containing dexamethasone, to improve drug permeability through the cornea. These solid nanoparticles facilitated topical passage of dexamethasone through the barriers of the eye. With the goal of combining the prevention of neovascularization and reduction of inflammation, Huang et al. (2017) designed a supramolecular hydrogel for co-delivery of dexamethasone sodium phosphate and Avastin ${ }^{\circledR}$ (an antiangiogenic agent). The supramolecular hydrogel was composed of MPEEG-PCL micelles and $\alpha$-cyclodextrin (an oligosaccharide cage). The in vivo studies showed that this supramolecular hydrogel significantly attenuated the inflammatory response and inhibited neovascularization through downregulation of the vascular endothelial growth factor (VEGF), CD31, and alpha-smooth muscle actin ( $\alpha$-SMA) expression.

Natural tears have trophic effects on epithelial cells because they contain vitamins, immunoglobulins, proteins, growth factors, and electrolytes (Grigoryeva et al., 2013). "Autologous serum eye drops" contain several essential nutrients like growth factors, vitamins, cytokines, proteins, and lipids that may assist in corneal re-epithelization. In addition to autologous serum, bandage-type contact lenses have been studied for repairing the corneal epithelial defect. Bandage contact lenses prevent the mechanical tension associated with blinking, therefore reducing necrosis and desquamation of the corneal epithelium (Ho and Mathews, 2017). Several studies have been done to combine the therapeutic effects of autologous serum and bandage contact lenses (Schrader et al., 2006; Choi and Chung, 2011). In a recent study, Wang et al. (2017) described the therapeutic outcomes of a combination of a topical $20 \%$ autologous serum and a silicone hydrogel contact lens in 12 patients during a 3-month followup period. All patients suffering from post-infection corneal epithelial defects were successfully treated; "corneal melting" during acute disease was successfully prevented. Studies have shown that breast milk performs similarly to autologous serum and natural tears. Thus, breast milk may accelerate epithelial wound healing because it contains anti-infection agents and growth factors. In one study, Asena et al. (2017) compared human breast milk with autologous serum and artificial tears in corneal epithelial wound healing. Their results showed that the presence of growth factors like TGF- $\beta$, insulin-like growth 
factor-1 (IGF-1), lipids, and vitamins in breast milk played important roles in epithelial and stromal wound healing in the cornea.

A novel therapeutic approach, described by Bazen and his colleague at Louisiana University, employed a neurotrophic and anti-angiogenic factors (pigment epithelium-derived factor [PEDF] combined with an essential fatty acid (docosahexaenoic acid, DHA] stimulated nerve regeneration in diabetic keratopathy (Bazan et al., 2014; He et al., 2015). In their recent study, they evaluated the therapeutic effects of topical application of PEDF and DHA over 2 weeks on the regeneration of the corneal sensory nerve in both wounded and unwounded diabetic corneas. They proposed some possible mechanisms for their results including neuroprotective and anti-oxidant actions of the PEDF+DHA, neurotrophic function, and the anti-inflammatory activity of this treatment. Figure 5 shows promoted wound healing on days one and two after injuries in the PEDF+DHA treated corneas (He et al., 2017b).

Another pharmaceutical agent, which has recently gained much attention, is a new type of extracellular matrix agent called ReGeneraTingAgent or RGTA (Arvola et al., 2016; Chappelet et al., 2017; Robciuc et al., 2018). This approach consists of engineered polymers designed to protect and replace cellular signaling proteins of the extracellular matrix (ECM), such as heparan sulfate. This unique property encourages the reconstruction of the ECM; therefore facilitating tissue wound healing (Barritault et al., 2017). Recently Gumus et al. (2017) investigated the topical effects of a biodegradable nanopolymer (alpha 1-6 polycarboxymethyl-sulfate) to mimic heparan sulfate in order to accelerate corneal re-epithelization and stromal healing, after epi-off corneal cross-linking technique. In fact, RGTAs were engineered to bind to heparan sulfate binding sites on proteins of the ECM. These agents are large enough to bridge between neighboring matrix proteins and recreate a cellular microenvironment and a microniche, where cells can respond appropriately to the cascade of signals involved in the wound healing process.

Many investigations have emphasized the role of several growth factors like platelet-derived growth factor (PDGF), VEGF, TGF- $\beta$, HGF, and tumor necrosis factor-beta (TNF- $\beta$ ) in the wound healing process. Among these growth factors, PDGF, TGF- $\beta$, and HGF played a pivotal role in modulating cell proliferation and myofibroblast differentiation. There is extensive literature available concerning the role of growth factors in corneal wound healing (Gallego-Muñoz et al., 2017; Sriram et al., 2017). In fact, a better understanding of the role of growth factors in corneal wound healing would likely lead to the development of new treatments. In one of the corresponding studies, Omoto et al. (2017) reported the effects of topical administration of HGF on inflammation of corneal epithelial cells. Their results demonstrated that topical application of HGF promoted corneal epithelial cell proliferation which was revealed by higher expression of the Ki-67 and p63 proliferation markers in HGF-treated mice. In addition, HGF treatment reversed the anti-proliferative effect of IL-1 $\beta$ in vitro, indicating that HGF actively suppressed the inflammatory environment in the corneal epithelium. On the other hand, HGF significantly reduced the infiltration of $\mathrm{CD} 45+$ inflammatory cells in the cornea (see Figure 6).

\section{Limbus Zone}

The limbus of the cornea forms a border between the corneal and conjunctival epithelium and its limbal stem cells (LSCs) are essential in the maintenance and repair of the adult cornea as they support the repair and regeneration of corneal epithelial tissue. In fact, this undulated limbal region is considered to be a niche for LSCs, which play a critical role in the corneal wound healing process. In limbal tissue engineering, like the other tissues, three factors affect the regeneration of injured tissues: cell availability, suitable and biocompatible scaffolds, and the presence of growth factors. In corneal disorders, depletion or the absence of LSCs results in impairment of the corneal wound healing process. Regarding tissue engineering, there are three approaches to remedy this deficiency. The first approach is cell transplantation using the desired cell population obtained in tissue culture. This approach has been considered as a type of corneal transplantation that was briefly discussed in the previous section. The second approach is cell transplantation using cells such as corneal epithelial, where stem cells are dissociated, cultivated on a supportive matrix (biosynthetic scaffold) like an amniotic membrane, fibrin gel or polymers, and then injected into the desired location in the cornea. The main problem in the last approach is the lack of stem cell enrichment because the stem cells which are used for transplantation contain heterogeneous cell populations. This deficiency might result in a graft failure (Rajendran et al., 2017). As an alternative solution, a few groups have recently focused on a new approach by mimicking the LSC microenvironment (niche) in which the LSCs live. In this section, new progress and emerging alternatives related to the second and third approaches will be discussed. Moreover, in order to get a broad overview of the subject, Figure 7 covers the evolutionary pathway of limbus regeneration over the past four decades.

\section{Cell Transplantation}

Using the bioengineered cornea is an alternative approach to addressing the aforementioned restrictions of corneal transplantation and artificial corneas. In most articles, tissue engineering of the outermost layer of the eye is known as ocular surface regeneration. In this approach, the optical and biomechanical characteristics of the tissue-engineered cornea are essential. For instance, tissue engineered cornea must be transparent and withstand about $10-20 \mathrm{~mm} \mathrm{Hg}$ of intraocular pressure. Therefore, biomaterial selection to produce appropriate scaffolds is an ongoing subject of investigation due to the emergence of tissue engineering. The main approaches in corneal tissue engineering to repair corneal defects can be divided into full thickness, stromal, epithelial, and endothelial types of regeneration. All of them involve the aid of a scaffold in combination with different cell types. Recent advances in corneal tissue engineering have been reviewed by Ghezzi et al. (2015). Meanwhile, the most studied biomaterials are amniotic membrane, collagen matrix, hydrogels, and other natural and synthetic polymers. After choosing the necessary materials, the physical, chemical, and biochemical modification 

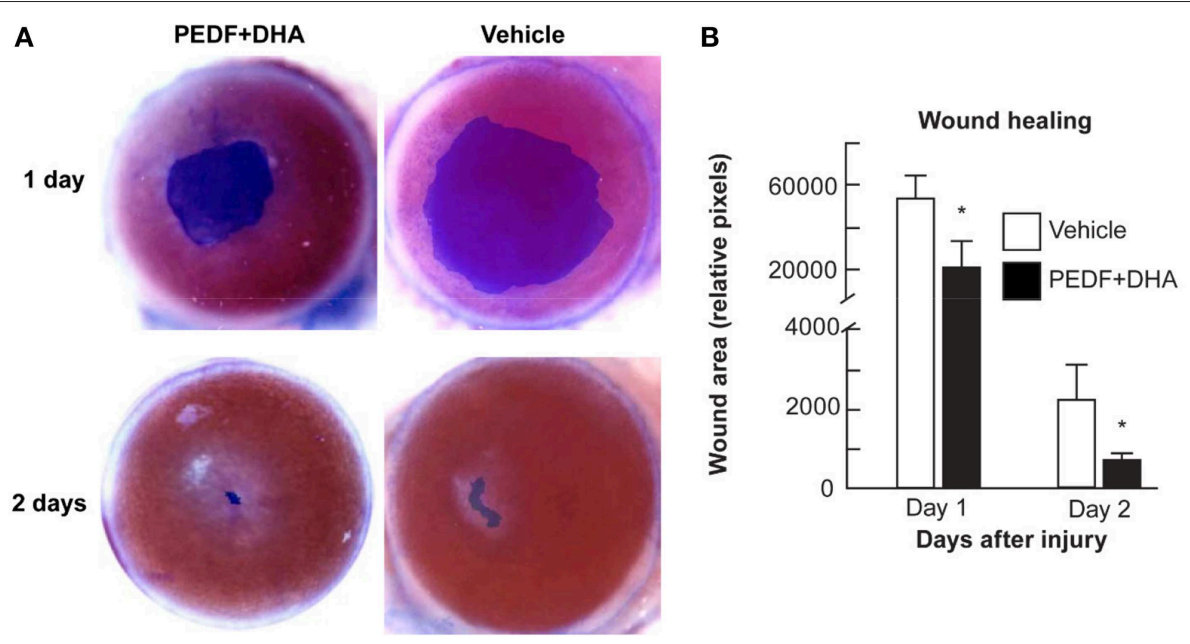

FIGURE 5 | Effect of PEDF+DHA treatment on wound healing in diabetic corneas. The right eyes of 16 mice with hyperglycemia for 10 weeks were injured and divided randomly into two groups and treated for 1 or 2 days with PEDF+DHA or vehicle. (A) The wounded corneas were stained with $0.5 \%$ methylene blue and photographed with a surgical microscopy through an attached digital camera. (B) Wounded area. Data is expressed as mean \pm SD $\left({ }^{*} p<0.05, n=4\right.$ mice/group). Reprinted with permission from He et al. (2017b).
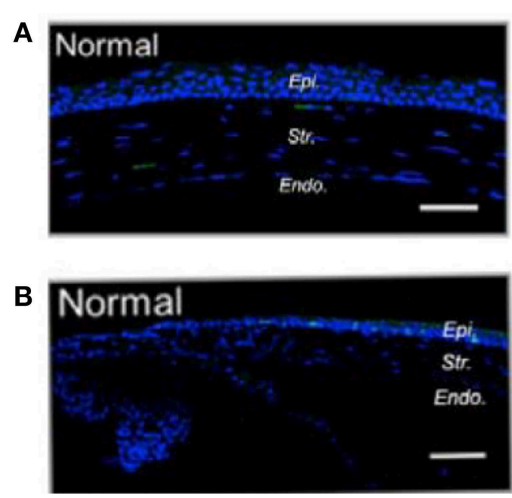
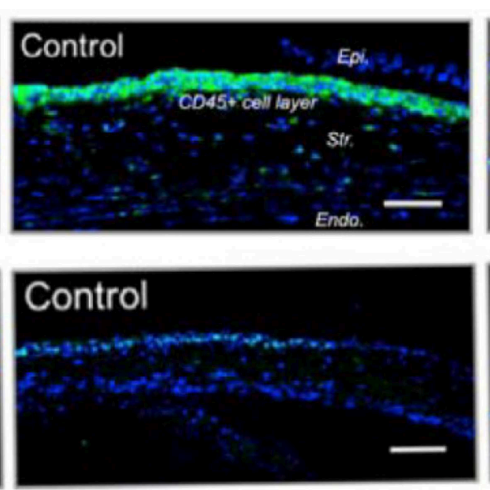
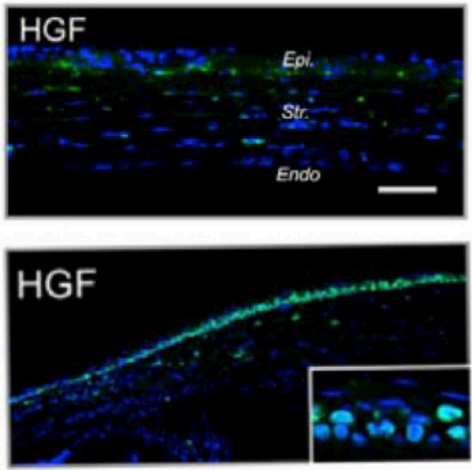

FIGURE 6 | Mechanical injury was induced in murine corneas by scraping the epithelium and either topical recombinant hepatocyte growth factor (HGF) was applied twice daily. Normal corneas without injury or injured corneas receiving MSA served as controls. Corneas were harvested at day 3 after injury. (A) Representative immunofluorescent images of sections of mouse cornea stained for Ki-67 (green) showing proliferating cells (scale bar, $100 \mathrm{~mm})$. (B) Representative immunofluorescence images of corneal cross sections showing higher expression of CD45 (green) in MSA-treated controls, compared to HGF-treated eyes (scale bar, $50 \mathrm{~mm}$ ). Reprinted with permission from Omoto et al. (2017).

of these materials play a pivotal role in the results. In this section, we have tried to review these modifications (Ismail et al., 2019; Wijnholds, 2019).

\section{Amniotic membrane (AM)}

Due to the specific characteristics which were described in detail in the last section, the gold standard substrate for the ex vivo expansion of LSCs remains AM. In recent years, different studies have focused on AM as a biological carrier in ex vivo reconstruction and transplantation of tissue engineered corneal epithelium (Sabater and Perez, 2017). Various aspects of this strategy have been investigated. One of these aspects is the relative transparency of the AM. In fact, AM features lower clarity than human cornea, and this lack of transparency restricts the use of $\mathrm{AM}$ as a carrier in corneal epithelial tissue engineering. Zhang et al. (2016) proposed a thinning protocol for the generation of ultra-thin amniotic membrane. The prepared AM was transparent and composed of a compact transparent layer which made it an ideal carrier for the construction of tissue engineered corneal epithelium (see Figure 8). Another challenge in using the AM is its potential to transmit infectious disease. Decellularization processes have been applied to various types of tissue for laboratory investigations and clinical applications. The most important aspects of any tissue decellularization protocol are to eliminate the risk of immune rejection and disease transmission, while at the same time retaining the underlying ECM structure. In this regard, Figueiredo et al. (2017) studied the potential use of decellularized human amniotic membrane 


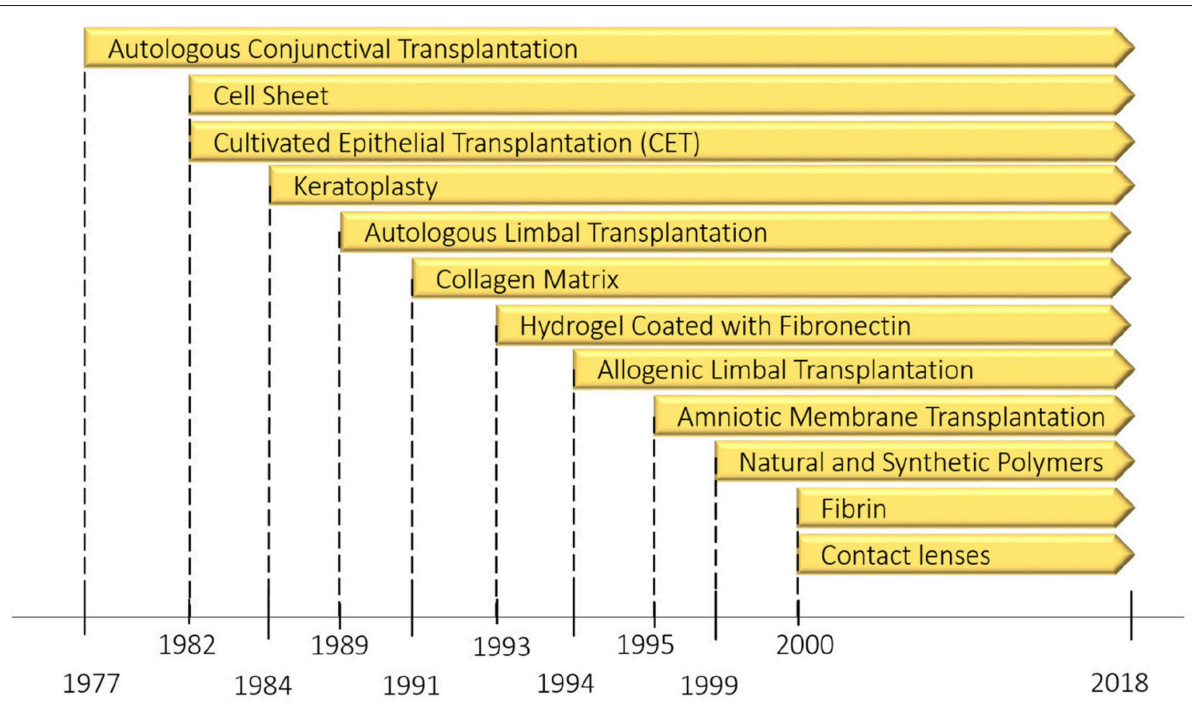

FIGURE 7 | The evolution pathway of ocular surface reconstruction investigations which started with autologous conjunctival transplantation in a patient with bilateral alkali burn in 1977 and have been continued with other methods specially limbus regeneration over the past four decades. Partially reprinted with permission from Nakamura et al. (2016).

for the ex vivo expansion of LSCs. They also evaluated, using gamma irradiation as a final sterilization step, the potential minimization of risk regarding disease transmission. Their results showed that ex vivo expansion of LSCs using an explant culture system occurred at a faster rate on decellularized human AM in comparison with fresh human AM. Human amniotic membrane is in clinical trials for corneal wound healing (Zakaria et al., 2014).

\section{Fibrin gel}

Fibrin was first introduced for wound healing applications in the form of tissue glue or engineered sheets. Fibrin is a natural protein involved in blood coagulation and, because of its biocompatibility, biodegradability, and its potential in wound healing, has attracted much interest in corneal wound healing (Ronfard et al., 1991; Pellegrini et al., 1999). In corneal surface reconstruction fibrin has been used as a glue for tissue adhesion or as a fibrin gel acting as a carrier of LSCs. The first studies on fibrin gel were carried out in early 2000s by Rama et al. (2001), Ronfard et al. (2000), Duchesne et al. (2001), and Han et al. (2002). Among these groups, Rama et al. published a long term follow-up (up to 10 years) in 2010, and their results showed that the renewal of corneal epithelium was attained in $76.6 \%$ of 112 patient eyes (Rama et al., 2010). Rama et al. also studied the 3T3 cell line cultured on fibrin matrix as a feederlayer which could supply metabolites to the LSCs. Recently, Lužnik et al. (2017) have studied the possibility of omitting the feeder-layer to achieve the xeno-free scaffold. Fibrin gel is in the clinical trial to investigate the cultivated oral mucosal epithelial cell sheet transplantation (COMET) of substrate-free cell sheets on reconstructing the ocular surface. In the study, fibrin-coated dishes with proteins inhibitor was used to adjust the degree of fibrin degradation (Hirayama et al., 2012). Nevertheless, studies on fibrin as a matrix have been overshadowed by other types of natural and synthetic polymers.

\section{Natural and synthetic polymers}

Natural and synthetic polymers have been the subject of several studies aiming to find a suitable carrier for the transfer of stem cells. In this regard, various polymers like hydrogels, self-assembling peptide nanofibers, collagen matrix, conductive polymers, and thermosensitive polymers have been studied (Deng et al., 2010; Zarrintaj et al., 2018a,b). Mechanical strength and transparency are the most important considerations in order to reconstruct the injured cornea (Fagerholm et al., 2010; Mozafari et al., 2019; Wicklein et al., 2019). In Table 2 pioneering studies on polymers as a substrate for corneal tissue engineering are summarized.

\section{Contact lens}

Despite the promising clinical outcomes of AM and fibrin gel, the study of other transplantation procedures has been continued. Among them, the carrier-free transfer method (cell sheets), and the use of a contact lens have gained more attention as they reduce the risk of xenobiotic infections and side effects from using non-Food and Drug Administration (FDA) approved biomaterials. Girolamo's group developed a novel autologous technique by using an FDA-approved soft contact lens as a carrier and bandage to protect the eye during LSC transplantation, thereby promoting corneal repair and regeneration (Di Girolamo et al., 2009). Their cell-laden siloxane-hydrogel contact lens was successful in reconstituting a healthy ocular surface in 16 patients with limbal stem cell deficiency (LSCD) (Bobba et al., 2015). Studies by several groups have reported attempts to modify the tissue adherence to the carrier, and to vary the stem cell type in order to improve the efficiency of the explant culture 
A
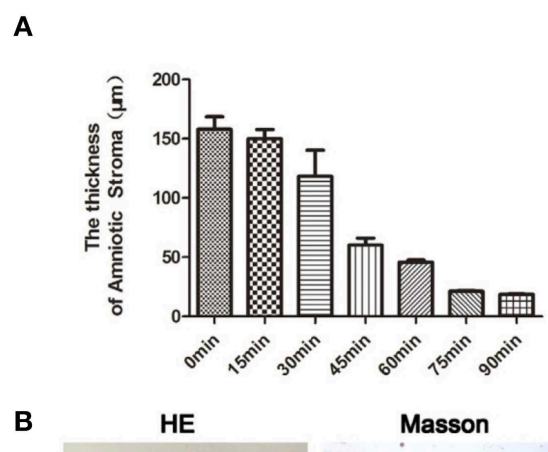

HE

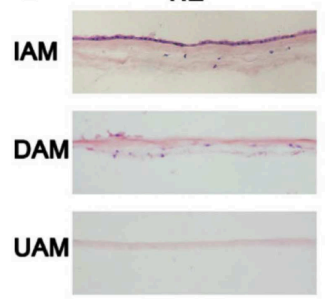

Masson

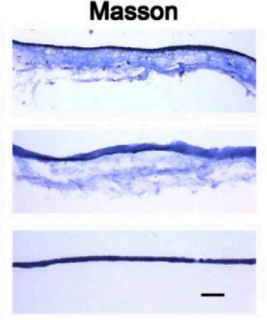

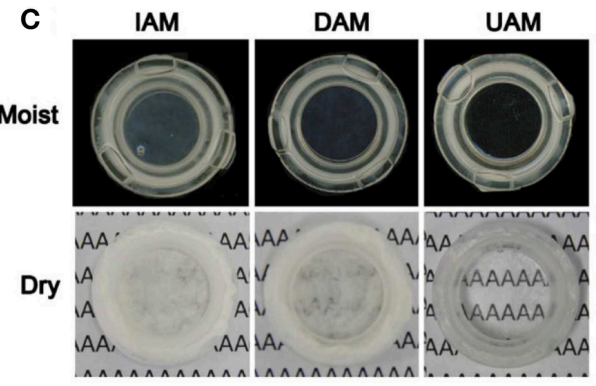

D

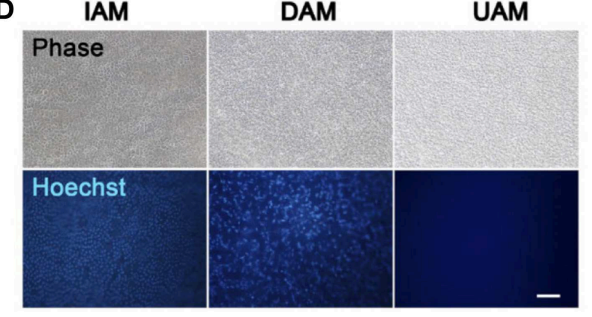

FIGURE 8 | The characteristics of ultra-thin amniotic membrane. (A) The thickness change of amniotic membrane after digestion with collagenase type IV for different time durations. (B) HandE and Masson trichrome staining of IAM, DAM, and UAM tissues (Bar: $100 \mu$ m). (C) Macroscopic views of IAM, DAM, and UAM were evaluated by photography scanning in moist form and light microscope in freeze dry form. (D) Hoechst whole mount staining of IAM, DAM, and UAM (Bar: $100 \mu$ m). Reprinted with permission from Zakaria et al. (2014).

system. Tóth et al. (2017) tested several methods for affixing the cells to prevent them from "floating off" the contact lens. Their results showed that in comparison with cyanoacrylate, silicon, and fibrin glue, suturing was the most efficient method to improve tissue adherence. In treating bilateral LSCD, the oral mucosal epithelium was shown to be a suitable autologous stem cell source. Accordingly, Zsebik et al. (2017) cultured human oral mucosal epithelium as a source for cell expansion on a lotrafilcon (a contact lens). They claimed that they established a xenobioticfree culture system from human oral mucosal explants on the contact lens surface.

\section{Cell sheet}

Over the past 30 years, conventional tissue engineering approaches (like the use of biodegradable scaffolds and/or injection of isolated cell suspensions) have been successful in the regeneration of different tissues (Koizumi and Okumura, 2019). However, these tissue engineering approaches still face some obstacles when applied for reconstruction of the ocular surface. There is a significant risk of infection when biological materials are employed, the attachment to the replacement site can be insufficient and can lead to degradation and loss of optical transparency. Sheet-like cell assemblies were introduced as a method to address these limitations (Green et al., 1979; Fagerholm et al., 2014). In this cell sheet technology, the desired cells are grown on a particular cell culture surface which allows reversal of cell adhesion, so an intact cell sheet can be transplanted to the host tissue without using scaffolds. In cell sheet technology several external stimuli have been applied to facilitate cell detachment like specific enzymes, temperature variation, magnetic force, electrochemical polarization, $\mathrm{pH}$ variation, polyelectrolytes, and illumination (Owaki et al., 2014). The cell sheet technique needs further study to become standardized before it can be used in routine clinical practices. One of the obstacles in this method is to find the optimal preservation medium to maintain the viability of the reconstructed tissue. Recently, Katori et al. (2016) introduced a new preservation medium for cell sheets (containing the antioxidant ebselen) derived from human corneal tissue and human oral mucosal epithelium. Another attempt to improve this technique was reported by Syed-Picard et al. (2018). They designed a highly organized structure with aligned microgrooves which directed parallel cell alignment, and allowed matrix organization, similar to that of native corneal stromal lamella (Buznyk et al., 2015). As a result, after transplantation of the engineered corneal tissues, the tissue sheets were incorporated into surrounding tissues and became transparent. A research group led by Okano at Tokyo University has studied the production of cell sheets from the corneal epithelium. They used a temperature responsive polymer to generate multilayered corneal epithelial sheets (Nishida et al., 2004a). Clinical results in four patients with the use of cultured autologous oral mucosal epithelial cell sheets showed that corneal transparency was restored, along with remarkable improvements in postoperative visual acuity (Nishida et al., 2004b). Recently they tried to optimize the cell sheet fabrication process in order to improve cell sheet quality and decrease risk of biological contamination. They developed a "cell cartridge" which acted as a closed culture system for regenerative medicine (Kobayashi et al., 2013; Nakajima et al., 2015). Self-lifting analogous tissue equivalent (SLATE) is a bio-fabricated, scaffold-free system which has been recently used in corneal tissue engineering. Peptide amphiphile used as 
TABLE 2 | Natural and synthetic polymers used for corneal wound healing.

\begin{tabular}{|c|c|c|c|c|}
\hline Carrier & Novelty & Target tissue & results & References \\
\hline Gelatin/ascorbic acid (AA) cryogel & $\begin{array}{l}\text { Using antioxidant } \\
\text { molecule-mediated structure }\end{array}$ & $\begin{array}{l}\text { Corneal stroma tissue } \\
\text { engineering }\end{array}$ & $\begin{array}{l}\text { Low-to-moderate AA loading demonstrated } \\
\text { better capability to enhance tissue matrix } \\
\text { regeneration and transparency maintenance } \\
\text { in animal model. }\end{array}$ & Luo et al., 2018 \\
\hline $\begin{array}{l}\text { Plastic compressed collagen } \\
\text { gel/electrospun } \\
\text { poly(lactic-co-glycolide) (PLGA) } \\
\text { mats }\end{array}$ & $\begin{array}{l}\text { Laser-perforating sandwich-like } \\
\text { hybrid construct }\end{array}$ & $\begin{array}{l}\text { Corneal epithelial and } \\
\text { stroma tissue engineering }\end{array}$ & $\begin{array}{l}\text { Co-culture of two kinds of cells for corneal } \\
\text { tissue reconstruction }\end{array}$ & Kong et al., 2017 \\
\hline Aligned silk membrane & $\begin{array}{l}\text { Multi-layered silk membrane with } \\
\text { neuropeptide substrate }\end{array}$ & $\begin{array}{l}\text { Corneal stroma tissue } \\
\text { engineering }\end{array}$ & $\begin{array}{l}\text { Differentiating periodontal ligament stem } \\
\text { cells (PDLSCs) toward keratocytes }\end{array}$ & Chen et al., 2017 \\
\hline $\begin{array}{l}\text { Silk/polyurethane hybrid } \\
\text { nanofibrous }\end{array}$ & $\begin{array}{l}\text { Using conjunctiva derived } \\
\text { mesenchymal stem } \\
\text { cell(CJMSCs) as a new source } \\
\text { for differentiation }\end{array}$ & $\begin{array}{l}\text { Corneal epithelial tissue } \\
\text { engineering }\end{array}$ & $\begin{array}{l}\text { Interconnected pore to accelerate nutrient } \\
\text { diffusion with sufficient mechanical } \\
\text { properties }\end{array}$ & $\begin{array}{l}\text { Soleimanifar et al., } \\
2017\end{array}$ \\
\hline $\begin{array}{l}\text { Thermosensitive chitosan-gelatin } \\
\text { hydrogel }\end{array}$ & $\begin{array}{l}\text { Human stromal cell-derived } \\
\text { factor-1 alpha (SDF-1 alpha) } \\
\text { loaded }\end{array}$ & $\begin{array}{l}\text { Corneal epithelial tissue } \\
\text { engineering }\end{array}$ & $\begin{array}{l}\text { Exogenous SDF-1 alpha promotes corneal } \\
\text { epithelium reconstruction through increase } \\
\text { local expression of other growth factor }\end{array}$ & Tang et al., 2017 \\
\hline $\begin{array}{l}\text { Collagen type-I coated } \\
\text { poly(lactic-co-glycolic acid) film }\end{array}$ & Using hybrid graft & $\begin{array}{l}\text { Corneal endothelial tissue } \\
\text { engineering }\end{array}$ & $\begin{array}{l}\text { Limiting the probability of non-specific } \\
\text { interaction between the construct and the } \\
\text { biological environment }\end{array}$ & Kim et al., $2017 \mathrm{a}$ \\
\hline Hyaluronic acid/pluronic hydrogel & $\begin{array}{l}\text { Injectable hydrogel with porcine } \\
\text { platelet rich plasma(P-PRP) }\end{array}$ & $\begin{array}{l}\text { Corneal endothelial tissue } \\
\text { engineering }\end{array}$ & Limiting hydrogel-induced cell death & Lin et al., 2017 \\
\hline Silk fibroin & $\begin{array}{l}\text { Developing artificial endothelial } \\
\text { graft }\end{array}$ & $\begin{array}{l}\text { Corneal endothelial tissue } \\
\text { engineering }\end{array}$ & $\begin{array}{l}\text { Appropriate biological properties beside } \\
\text { mechanical properties that allowed its use in } \\
\text { a Descemet membrane endothelial } \\
\text { keratoplasty }\end{array}$ & Vázquez et al., 2017 \\
\hline $\begin{array}{l}\text { Poly(glycerol sebacate)PGS-poly } \\
\text { ( } \varepsilon \text {-caprolactone) PCL nanofibrous }\end{array}$ & $\begin{array}{l}\text { Elastomeric biodegradable } \\
\text { scaffold }\end{array}$ & $\begin{array}{l}\text { Corneal endothelial tissue } \\
\text { engineering }\end{array}$ & $\begin{array}{l}\text { Semi-transparent and highly elastic aligned } \\
\text { nanofibrous PGS-PCL blended scaffold }\end{array}$ & Salehi et al., 2017 \\
\hline $\begin{array}{l}\text { Sequential hybrid crosslinking } \\
\text { gelatin methacrylate }\end{array}$ & $\begin{array}{l}\text { Hydrogel patterning with } \\
\text { Nanoscale resolution }\end{array}$ & $\begin{array}{l}\text { Corneal endothelial tissue } \\
\text { engineering }\end{array}$ & $\begin{array}{l}\text { Increased mechanical strength, transparent } \\
\text { and provide adequate nutrient transport }\end{array}$ & Rizwan et al., 2017 \\
\hline $\begin{array}{l}\text { Gelatin microcarriers Functionalized } \\
\text { with oxidized hyaluronic acid }\end{array}$ & $\begin{array}{l}\text { Using cell-containing } \\
\text { microcarriers }\end{array}$ & $\begin{array}{l}\text { Corneal stromal tissue } \\
\text { engineering }\end{array}$ & $\begin{array}{l}\text { Microcarriers well tolerated and can be } \\
\text { degraded by endogenous enzymes } \\
\text { following intracameral implantation }\end{array}$ & Lai and Ma, 2017 \\
\hline $\begin{array}{l}\text { Short collagen-like peptides } \\
\text { conjugated to polyethylene glycol }\end{array}$ & $\begin{array}{l}\text { Using synthetic and } \\
\text { customizable analogs }\end{array}$ & $\begin{array}{l}\text { Corneal endothelial tissue } \\
\text { engineering }\end{array}$ & $\begin{array}{l}\text { Promoting corneal regeneration through } \\
\text { stimulation of extracellular vesicle production } \\
\text { by endogenous host cells that migrate into } \\
\text { the scaffold }\end{array}$ & $\begin{array}{l}\text { Jangamreddy et al., } \\
2018\end{array}$ \\
\hline
\end{tabular}

a surface template provides a platform to control the structural, mechanical, and biofunctional properties of the SLATE to replace damaged corneal tissue. In this study, SLATEs were implanted in a rabbit corneal. After a 9-months follow-up, SLATE was well integrated with surrounding hot tissue without a sign of rejection and provoking inflammation (Gouveia et al., 2017).

\section{Artificial Limbus}

"Form follows function" is a well-known concept accepted as a principle in the field of modernist architecture; although it is also universally observed throughout the nature. According to this principle, the shape of an object should be predominantly based upon its intended function or purpose (Griffith and Harkin, 2014; Ghaffari et al., 2016). The application of this principle in the engineering of limbus tissue can be translated into mimicking the three-dimensional morphological structure of tissues in order to provide a specific niche to support stem cells. In the last decade, an emphasis on the importance of architectural features in tissues is a sign that attention is being paid to this principle. Meanwhile, the study of the stem cell microenvironment (niche) and its highly regulated and specific structure has attracted more attention (Rahmati and Mozafari, 2019b). Stem cells are defined by their ability to self-renew and to participate in the regeneration of damaged tissues, and their niche exhibits distinct anatomical and biochemical features in comparison with their surrounding tissue. On the other hand, some studies have shown niche morphology was altered in limbal stem cell deficiency, caused by disease or increased age (Zheng and Xu, 2008; Lagali et al., 2013). Researchers have attempted to characterize and quantify the stem cell niche by various visualization methods, and to utilize these data to fabricate artificial niches for stem cells. Several techniques are now under investigation in order to mimic the niche structure for corneal repair (Ortega et al., 2012). In a recent study, Claeyssens et al. focused on the characterization and evaluation of the impact of the "Palisades of Vogt" structure on the function of limbal stem cells. 

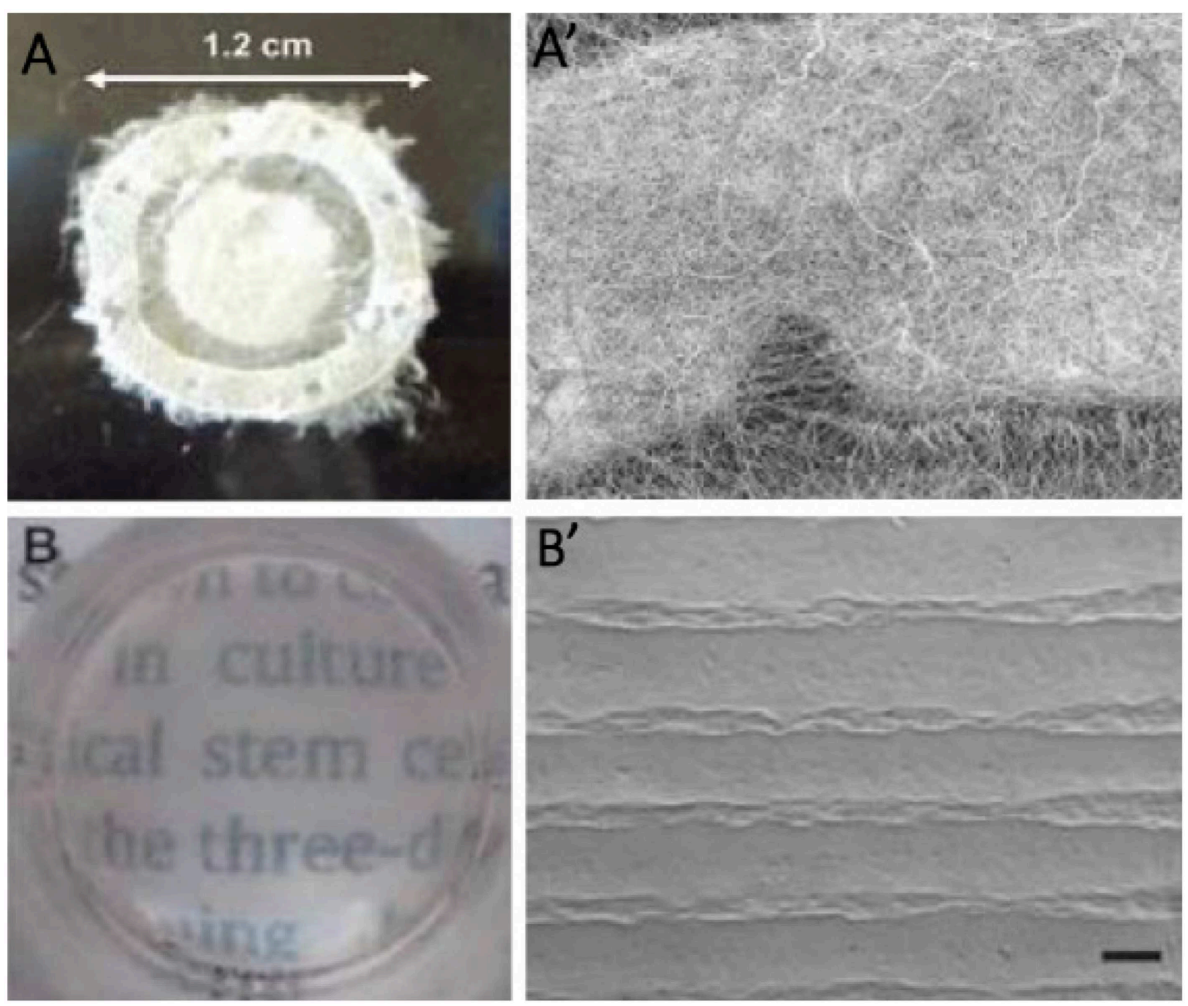

FIGURE 9 | (A) Detail of electrospun outer ring with $1.2 \mathrm{~cm}$ of diameter, ( $\mathbf{A}^{\prime}$ ) SEM micrograph of a section of the electrospun scaffold showing a horseshoe electrospun micropocket. (B) Stability and transparency of cultured RAFT (Ortega et al., 2013b). (B') SEM image of bioengineered limbal crypts on the RAFT surface. Scale bar $200 \mu \mathrm{m}$. Reprinted with permission from Levis and Daniels (2016).

They combined micro-stereolithography and electrospinning to fabricate PLGA rings containing microfabricated pockets. In this study, they reported the physical and protective properties of the niche. Their results showed that micropockets of the PLGA ring played a pivotal role in cell migration and directionality (Ortega et al., 2013b, 2014a,b). They also studied the fabrication of polyethylene glycol diacrylate rings containing microfeatures, which were modified by biotinylated fibronectin. In their study, the use of ECM proteins stimulated limbal cell outgrowth and migration (Ortega et al., 2013a). Levis group at UCL Institute of Ophthalmology have developed a method to create bioengineered limbal crypts with a functional 3D niche architecture (Levis et al., 2013). This novel process for production was referred to as "Real Architecture For 3D Tissue" or RAFT $^{\mathrm{TM}}$. Figure 9 illustrates two kinds of cultured RAFT limbal crypts. This new 3D cell culture system uses physiologically relevant concentrations of collagen to create the most natural environment for cells. The custom molded micro-ridges on the surface of the thin collagen resembles the dimensions of the stromal crypts in the human limbus. They also studied the effect of the 3D topography and ECM markers on the human limbal epithelium. The bioengineered limbal crypts expressed putative limbal epithelial stem cell markers like $\Delta$ Np63a and BMil and also produced basement membrane proteins like laminin- $\beta 1$ and laminin- $\gamma 3$ (Massie et al., 2014; Levis and Daniels, 2016).

\section{CONCLUSION AND FUTURE OUTLOOK}

From the earliest concepts such as replacement of the opaque cornea, to cornea wound healing and regeneration, ophthalmologists, and material scientists worldwide have faced a variety of challenges. Advances in visualization techniques and histology have made significant progress in the fundamental understanding of cornea structure and its microenvironment. Due to this valuable information and nanotechnology advances, therapeutic strategies in devastating corneal diseases have turned from corneal replacement into corneal wound healing and regeneration (Kargozar and Mozafari, 2018). Consequently, studies on the limbus zone and immune and angiogenic privilege have attracted more attention. In addition, the exploration of cell signaling in the natural process of wound healing and the attempts to mimic this process have opened new horizons in corneal disease treatment.

Most of the suggested treatments have shown promising results for wound healing at the ocular surface, and entire thickness dystrophies were neglected. While, in order to reduce transplantation of a donor cornea, tissue engineering of the whole thickness of the cornea must be considered. Corneal stromal and endothelium tissue engineering have recently shown noticeable progress (Matthyssen et al., 2018). However, more focus is needed on biomimetic strategies, like employing a combination of cell 
signaling agents with tissue engineering. Rho-kinase (ROCK) inhibitor is a serine/threonine protein kinase that participates in regulating cell signaling pathway. Recently ROCK has been introduced as an innovative therapeutic agent for corneal endothelial dystrophy (Han et al., 2018). The compilation of these approaches can be a promising method for visual rehabilitation in patients suffering from corneal dystrophies.

Until now, most studies have worked on introducing new materials and biochemical approaches in cornea wound healing and regeneration; while paying attention to physical properties of these approaches might be a leap in this area. For instance Long et al. have tried to use a cross-linking agent in collagen membrane to regulate collagen fibril spacing and therefore improve optical clarity of collagen and increase permeability of neurites (Long et al., 2018). Hence, advances in visualization techniques will help to improve corneal physical structure identification that, in combination with material science, will lead to new sights in the typical treatment approaches. Sliplamp biomacroscopy, optical coherence tomography (OCT), in vivo confocal fluorescence microscopy, and full-field optical microscopy are part of visualization techniques which help to quantify corneal architecture (Grieve et al., 2015; Werkmeister et al., 2017). According to previous studies, investigation on visualization methods would boost corneal medical treatments.

Considering the remarkable role of stem cells in tissue regeneration, a large part of future studies is expected to focus on the deployment of stem cells on cornea wound

\section{REFERENCES}

Abdel-Naby, W., Cole, B., Liu, A., Liu, J., Wan, P., Guaiquil, V. H., et al. (2017). Silk-derived protein enhances corneal epithelial migration, adhesion, and proliferation. Invest. Ophthalmol. Visual Sci. 58, 1425-1433. doi: 10.1167/iovs.16-19957

Alarcon, E., Vulesevic, B., Argawal, A., Ross, A., Bejjani, P., Podrebarac, J., et al. (2016). Coloured cornea replacements with anti-infective properties: expanding the safe use of silver nanoparticles in regenerative medicine. Nanoscale 8, 6484-6489. doi: 10.1039/C6NR01339B

Ambati, B. K., Joussen, A. M., Kuziel, W. A., Adamis, A. P., and Ambati, J. (2003). Inhibition of corneal neovascularization by genetic ablation of CCR2. Cornea 22, 465-467. doi: 10.1097/00003226-200307000-00013

Arvola, R. P., Robciuc, A., and Holopainen, J. M. (2016). Matrix regeneration therapy: a case series of corneal neurotrophic ulcers. Cornea 35, 451-455. doi: 10.1097/ICO.0000000000000759

Asena, L., Suveren, E. H., Karabay, G., and Dursun Altinors, D. (2017). Human breast milk drops promote corneal epithelial wound healing. Curr. Eye Res. 42, 506-512. doi: 10.1080/02713683.2016.1223318

Aucoin, L., Griffith, C. M., Pleizier, G., Deslandes, Y., and Sheardown, H. (2002). Interactions of corneal epithelial cells and surfaces modified with cell adhesion peptide combinations. J. Biomater. Sci. 13, 447-462. doi: $10.1163 / 156856202320253956$

Baino, F., Ferraris, S., Miola, M., Perero, S., Verné, E., Coggiola, A., et al. (2016). Novel antibacterial ocular prostheses: proof of concept and physico-chemical characterization. Mater. Sci. Eng. C 60, 467-474. doi: 10.1016/j.msec.2015.11.075

Baradaran-Rafii, A., Eslani, M., Haq, Z., Shirzadeh, E., Huvard, M. J., and Djalilian, A. R. (2017). Current and upcoming therapies for ocular surface chemical injuries. Ocular Surf. 15, 48-64. doi: 10.1016/j.jtos.2016.09.002

Barritault, D., Gilbert-Sirieix, M., Rice, K. L., Siñeriz, F., Papy-Garcia, D., Baudouin, C., et al. (2017). RGTA ${ }^{\circledR}$ or ReGeneraTing Agents mimic healing and regeneration (Rahmati et al., 2018). Several studies have been done to isolate and characterize multipotent stem cells from various tissues in order to use their great potential in regenerative medicine. Bone marrow-derived mesenchymal stem cells (Islam et al., 2018), human umbilical cord mesenchymal stem cells (Yamashita et al., 2018), postnatal periodontal ligament (Yam et al., 2018), and limbal stem cells (Inatomi et al., 2018; Sasamoto et al., 2018) are recently studied stem cells sources in corneal wound healing and regeneration. Saghizadeh et al. (2017) have recently reviewed all major stem cells usage in corneal wound healing. On the other hand, developing innovative methods to produce $3 \mathrm{D}$ tissue-like architecture has allowed mimicking the microarchitecture and physiology of the native cornea. In this regards $3 \mathrm{D}$ microfabrication methods are promising approaches in designing cornea substitutes (Prina et al., 2017; Ludwig et al., 2018). Among additive manufacturing methods, study on bioprinting and the development of bioinks provides great promise regarding the fabrication of human corneal substitutes that mimic the structure of native corneal tissues (Isaacson et al., 2018; Sorkio et al., 2018).

\section{AUTHOR CONTRIBUTIONS}

MoM and RA wrote the first draft. SO and MG wrote the first draft and analyzed the data. FM and MaM, created the idea, managed the team, and finalized the draft.

heparan sulfate in regenerative medicine: from concept to curing patients. Glycoconjugate J. 34, 325-338. doi: 10.1007/s10719-016-9744-5

Bazan, H. E., He, J., Kakazu, A. H., Cortina, M. S., Musarrat, F., and Neumann, D. (2014). Treatment with pigment epithelial-derived factor (PEDF) plus docosahexaenoic acid (DHA) increases corneal sensitivity and reduces inflammatory response after HSV-1 infection. Invest. Ophthalmol. Visual Sci. 55, 1467-1467. doi: 10.1016/j.exer.2017.06.015

Bian, F., Xiao, Y., Zaheer, M., Volpe, E. A., Pflugfelder, S. C., Li, D. Q., et al. (2017). Inhibition of NLRP3 inflammasome pathway by butyrate improves corneal wound healing in corneal alkali burn. Int. J. Mol. Sci. 18:562. doi: $10.3390 /$ ijms 18030562

Bobba, S., Chow, S., Watson, S., and Di Girolamo, N. (2015). Clinical outcomes of xeno-free expansion and transplantation of autologous ocular surface epithelial stem cells via contact lens delivery: a prospective case series. Stem Cell Res. Ther. 6:23. doi: 10.1186/s13287-015-0009-1

Buznyk, O., Pasyechnikova, N., Islam, M. M., Iakymenko, S., Fagerholm, P., and Griffith, M. (2015). Bioengineered corneas grafted as alternatives to human donor corneas in three high-risk patients. Clin. Transl. Sci. 8, 558-562. doi: $10.1111 /$ cts. 12293

Cano, L., Gutierrez, J., and Tercjak, A. (2013). Rutile TiO2 nanoparticles dispersed in a self-assembled polystyrene-block-polymethyl methacrylate diblock copolymer template. J. Phys. Chem. C 117, 1151-1156. doi: 10.1021/jp309335x

Chappelet, M. A., Bernheim, D., Chiquet, C., and Aptel, F. (2017). Effect of a new matrix therapy agent in persistent epithelial defects after bacterial keratitis treated with topical fortified antibiotics. Cornea 36, 1061-1068. doi: 10.1097/ICO.000000000 0001261

Chen, J., Zhang, W., Kelk, P., Backman, L. J., and Danielson, P. (2017). Substance $P$ and patterned silk biomaterial stimulate periodontal ligament stem cells to form corneal stroma in a bioengineered threedimensional model. Stem Cell Res. Ther. 8:260. doi: 10.1186/s13287-017$0715-\mathrm{y}$ 
Choi, J. A., and Chung, S. H. (2011). Combined application of autologous serum eye drops and silicone hydrogel lenses for the treatment of persistent epithelial defects. Eye Contact Lens 37, 370-373. doi: 10.1097/ICL.0b013e318233c9bb

Cocucci, E., Racchetti, G., and Meldolesi, J. (2009). Shedding microvesicles: artefacts no more. Trends Cell Biol. 19, 43-51. doi: 10.1016/j.tcb.2008.11.003

Cortina, M. S., and De La Cruz, J. (2015). Keratoprostheses and Artificial Corneas: Fundamentals Surgical Applications. Heidelberg: Springer. doi: 10.1007/978-3-642-55179-6

Cui, R., Lu, Q., Teng, Y., Li, K., and Li, N. (2017). Chitosan promoted the Corneal epithelial wound healing via activation of ERK pathway. Curr. Eye Res. 42, 21-27. doi: 10.3109/02713683.2016.1145235

Cursiefen, C. (2007). "Immune privilege and angiogenic privilege of the cornea," in Immune Response and the Eye, eds J. Y. Niederkorn and H. J. Kaplan (Basel: Karger Publishers), 50-57. doi: 10.1159/000099253

Dai, T., Tanaka, M., Huang, Y. Y., and Hamblin, M. R. (2011). Chitosan preparations for wounds and burns: antimicrobial and wound-healing effects. Expert Rev. Anti-Infect. Ther. 9, 857-879. doi: 10.1586/eri.11.59

Deng, C., Li, F., Hackett, J. M., Chaudhry, S. H., Toll, F. N., Toye, B., et al. (2010). Collagen and glycopolymer based hydrogel for potential corneal application. Acta Biomater. 6, 187-194. doi: 10.1016/j.actbio.2009.07.027

Di Girolamo, N., Bosch, M., Zamora, K., Coroneo, M. T., Wakefield, D., and Watson, S. L. (2009). A contact lens-based technique for expansion and transplantation of autologous epithelial progenitors for ocular surface reconstruction. Transplantation 87, 1571-1578. doi: 10.1097/TP.0b013e3181a4bbf2

Dohlman, C. H., Cruzat, A., and White, M. (2014). The Boston keratoprosthesis 2014: a step in the evolution of artificial corneas. Spektrum der Augenheilkunde 28, 226-233. doi: 10.1007/s00717-014-0240-7

Duchesne, B., Tahi, H., and Galand, A. (2001). Use of human fibrin glue and amniotic membrane transplant in corneal perforation. Cornea 20, 230-232. doi: 10.1097/00003226-200103000-00027

Duncker, G. I., Storsberg, J., and Müller-Lierheim, W. G. (2014). The fully synthetic, bio-coated MIRO ${ }^{\circledR}$ CORNEA UR keratoprosthesis: development, preclinical testing, and first clinical results. Spektrum der Augenheilkunde 28, 250-260. doi: 10.1007/s00717-014-0243-4

Ellenberg, D., Azar, D. T., Hallak, J. A., Tobaigy, F., Han, K. Y., Jain, S., et al. (2010). Novel aspects of corneal angiogenic and lymphangiogenic privilege. Prog. Retinal Eye Res. 29, 208-248. doi: 10.1016/j.preteyeres.2010. 01.002

Fagerholm, P., Lagali, N. S., Merrett, K., Jackson, W. B., Munger, R., Liu, Y., et al. (2010). A biosynthetic alternative to human donor tissue for inducing corneal regeneration: 24-month follow-up of a phase 1 clinical study. Sci. Trans. Med. 2:46ra61. doi: 10.1126/scitranslmed.3001022

Fagerholm, P., Lagali, N. S., Ong, J. A., Merrett, K., Jackson, W. B., Polarek, J. W., et al. (2014). Stable corneal regeneration four years after implantation of a cell-free recombinant human collagen scaffold. Biomaterials 35, 2420-2427. doi: 10.1016/j.biomaterials.2013.11.079

Falcinelli, G., Falsini, B., Taloni, M., Colliardo, P., and Falcinelli, G. (2005). Modified osteo-odonto-keratoprosthesis for treatment of corneal blindness: long-term anatomical and functional outcomes in 181 cases. Arch. Ophthalmol. 123, 1319-1329. doi: 10.1001/archopht.123.10.1319

Falcinelli, G., Missiroli, A., Petitti, V., and Pinna, C. (1987). Osteo odonto keratoprosthesis up to date. Acta XXV Concilium Ophthalmol. Milan 2, 2772-2776.

Figueiredo, G., Bojic, S., Rooney, P., Wilshaw, S.-P., Connon, C., Gouveia, R., et al. (2017). Gamma-irradiated human amniotic membrane decellularised with sodium dodecyl sulfate is a more efficient substrate for the ex vivo expansion of limbal stem cells. Acta Biomater. 61, 124-133. doi: 10.1016/j.actbio.2017. 07.041

Fischak, C., Klaus, R., Werkmeister, R. M., Hohenadl, C., Prinz, M., Schmetterer, L., et al. (2017). Effect of topically administered chitosan-N-acetylcysteine on corneal wound healing in a rabbit model. J. Ophthalmol. 2017:5192924. doi: 10.1155/2017/5192924

Gallego-Muñoz, P., Ibares-Frías, L., Valsero-Blanco, M. C., CantalapiedraRodriguez, R., Merayo-Lloves, J., and Martínez-García, M. C. (2017). Effects of TGF $\beta 1$, PDGF-BB, and bFGF, on human corneal fibroblasts proliferation and differentiation during stromal repair. Cytokine 96, 94-101. doi: $10.1016 /$ j.cyto.2017.03.011
Ghaffari, M., Moztarzadeh, S., Rahmanian, F., Yazdanpanah, A., Ramedani, A., Mills, D. K., et al. (2016). "Nanobiomaterials for bionic eye: vision of the future," in Engineering of Nanobiomaterials, ed A. Grumezescu (Amsterdam: Elsevier), 257-285. doi: 10.1016/B978-0-323-41532-3.00008-7

Ghezzi, C. E., Rnjak-Kovacina, J., and Kaplan, D. L. (2015). Corneal tissue engineering: recent advances and future perspectives. Tissue Eng. Part B Rev. 21, 278-287. doi: 10.1089/ten.teb.2014.0397

Gholipourmalekabadi, M., Samadikuchaksaraei, A., Seifalian, A. M., Urbanska, A. M., Ghanbarian, H., Hardy, J. G., et al. (2018). Silk fibroin/amniotic membrane 3D bi-layered artificial skin. Biomed. Mater. 13:035003. doi: 10.1088/1748-605X/aa999b

Gonzalez-Paredes, A., Torres, D., and Alonso, M. J. (2017). Polyarginine nanocapsules: a versatile nanocarrier with potential in transmucosal drug delivery. Int. J. Pharma. 529, 474-485. doi: 10.1016/j.ijpharm.2017.07.001

Gouveia, R. M., González-Andrades, E., Cardona, J. C., González-Gallardo, C., Ionescu, A. M., Garzon, I., et al. (2017). Controlling the 3D architecture of Self-Lifting Auto-generated Tissue Equivalents (SLATEs) for optimized corneal graft composition and stability. Biomaterials 121, 205-219. doi: $10.1016 /$ j.biomaterials.2016.12.023

Green, H., Kehinde, O., and Thomas, J. (1979). Growth of cultured human epidermal cells into multiple epithelia suitable for grafting. Proc. Natl. Acad. Sci. 76, 5665-5668. doi: 10.1073/pnas.76.11.5665

Grieve, K., Ghoubay, D., Georgeon, C., Thouvenin, O., Bouheraoua, N., Paques, M., et al. (2015). Three-dimensional structure of the mammalian limbal stem cell niche. Exp. Eye Res. 140, 75-84. doi: 10.1016/j.exer.2015.08.003

Griffith, M., Alarcon, E. I., and Brunette, I. (2016). Regenerative approaches for the cornea. J. Intern. Med. 280, 276-286. doi: 10.1111/joim.12502

Griffith, M., and Harkin, D. G. (2014). Recent advances in the design of artificial corneas. Curr. Opin. Ophthalmol. 25, 240-247. doi: 10.1097/ICU.0000000000 000049

Grigoryeva, A., Eremina, A., Druzhinin, I., Chernykh, D., Varvarinsky, E., and Ryabchikova, E. (2013). Diagnostic potential of the electron microscopic analysis of human lacrimal fluid. Oftal'mokhirurgiya 4, 104-107.

Gronkiewicz, K. M., Giuliano, E. A., Sharma, A., and Mohan, R. R. (2017). Effects of topical hyaluronic acid on corneal wound healing in dogs: a pilot study. Veter. Ophthalmol. 20, 123-130. doi: 10.1111/vop.12379

Gumus, K., Guerra, M. G., de Melo Marques, S. H., Karaküçük, S., and Barritault, D. (2017). A new matrix therapy agent for faster corneal healing and less ocular discomfort following epi-off accelerated corneal cross-linking in progressive keratoconus. J. Refract. Surg. 33, 163-170. doi: 10.3928/1081597X-2016 1206-07

Haagdorens, M., Van Acker, S. I., Van Gerwen, V., N.í, Dhubhghaill, S., and Koppen, C., Tassignon, M.-J., et al. (2016). Limbal stem cell deficiency: current treatment options and emerging therapies. Stem Cells Int. 2016:9798374. doi: 10.1155/2016/9798374

Han, B., Schwab, I. R., Madsen, T. K., and Isseroff, R. R. (2002). A fibrinbased bioengineered ocular surface with human corneal epithelial stem cells. Cornea 21, 505-510. doi: 10.1097/00003226-20020700000013

Han, K. Y., Dugas-Ford, J., Seiki, M., Chang, J. H., and Azar, D. T. (2015a). Evidence for the involvement of MMP14 in MMP2 processing and recruitment in exosomes of corneal fibroblasts. Invest. Ophthalmol. Visual Sci. 56, 5323-5329. doi: 10.1167/iovs.14-14417

Han, K. Y., Tran, J. A., Chang, J. H., Azar, D. T., and Zieske, J. D. (2017). Potential role of corneal epithelial cell-derived exosomes in corneal wound healing and neovascularization. Sci. Rep. 7:40548. doi: 10.1038/sr ep40548

Han, S. B., Dunlap, K., and Akpek, E. K. (2015b). "Boston KPro type I in the pediatric age group," in Keratoprostheses and Artificial Corneas, eds M. Soledad Cortina and J. de la Cruz (New York, NY: Springer), 145-152. doi: 10.1007/978-3-642-55179-6_17

Han, S. B., Liu, Y. C., Mohamed-Noriega, K., and Mehta, J. S. (2018). Application of novel drugs for corneal cell regeneration. J. Ophthalmol. 2018:1215868. doi: 10.1155/2018/1215868

He, H., Kuriyan, A. E., Su, C. W., Mahabole, M., Zhang, Y., Zhu, Y. T., et al. (2017a). Inhibition of proliferation and epithelial mesenchymal transition in retinal pigment epithelial cells by heavy chain-hyaluronan/pentraxin 3. Sci. Rep. 7:43736. doi: $10.1038 /$ srep43736 
He, J., Cortina, M. S., Kakazu, A., and Bazan, H. E. (2015). The PEDF neuroprotective domain plus DHA induces corneal nerve regeneration after experimental surgery. Invest. Ophthalmol. Visual Sci. 56, 3505-3513. doi: 10.1167/iovs.15-16755

He, J., Pham, T. L., Kakazu, A., and Bazan, H. E. (2017b). Recovery of corneal sensitivity and increase in nerve density and wound healing in diabetic mice after PEDF plus DHA treatment. Diabetes 2017:170249. doi: 10.2337/db17-0249

Hille, K. (2018). Long-term outcome of keratoprosthesis with biological support. Der Ophthalmol. 115, 5-11. doi: 10.1007/s00347-017-0503-1

Hirayama, M., Satake, Y., Higa, K., Yamaguchi, T., and Shimazaki, J. (2012). Transplantation of cultivated oral mucosal epithelium prepared in fibrincoated culture dishes. Invest. Ophthalmol. Visual Sci. 53, 1602-1609. doi: 10.1167/iovs.11-7847

Ho, D. K., and Mathews, J. P. (2017). Folded bandage contact lens retention in a patient with bilateral dry eye symptoms: a case report. BMC Ophthalmol. 17:116. doi: 10.1186/s12886-017-0505-4

Huang, J., Wang, W., Yu, J., Yu, X., Zheng, Q., Peng, F., et al. (2017). Combination of dexamethasone and Avastin ${ }^{\circledR}$ by supramolecular hydrogel attenuates the inflammatory corneal neovascularization in rat alkali burn model. Colloids Surfaces B Biointerfaces 159, 241-250. doi: 10.1016/j.colsurfb.2017.07.057

Huang, Y., Dong, Y., Wang, L., Du, G., Yu, J., Song, J., et al. (2012). Long-term outcomes of MICOF keratoprosthesis in the end stage of autoimmune dry eyes: an experience in China. Br. J. Ophthalmol. 96, 28-33. doi: 10.1136/bjo.2010.193029

Huhtinen, R., Sandeman, S., Rose, S., Fok, E., Howell, C., Fröberg, L., et al. (2013). Examining porous bio-active glass as a potential osteo-odonto-keratoprosthetic skirt material. J. Mater. Sci. 24, 1217-1227. doi: 10.1007/s10856-013-4881-x

Hwang, Y., and Kim, G. (2016). Evaluation of stability and biocompatibility of PHEMA-PMMA keratoprosthesis by penetrating keratoplasty in rabbits. Lab. Anim. Res. 32, 181-186. doi: 10.5625/lar.2016.32.4.181

Inatomi, T., Nakamura, T., Koizumi, N., Sotozono, C., and Kinoshita, S. (2018). "Ocular surface reconstruction using cultivated corneal and oral mucosal epithelial transplantation," in Ocular Surface Disease, ed A. R. Djalilian (New York, NY: Springer), 349-361. doi: 10.1007/978-3-319-15823-5_23

Isaacson, A., Swioklo, S., and Connon, C. (2018). 3D bioprinting of a corneal stroma equivalent. Exp. Eye Res. 173, 188-193. doi: 10.1016/j.exer.2018.05.010

Islam, M. M., Buznyk, O., Reddy, J. C., Pasyechnikova, N., Alarcon, E. I., Hayes, S., et al. (2018). Biomaterials-enabled cornea regeneration in patients at high risk for rejection of donor tissue transplantation. NPJ Regenerat. Med. 3:2. doi: 10.1038/s41536-017-0038-8

Ismail, S., McGhee, J. J., Li, Y., Mathan, J. J., Yoon, J. J., Wadhwa, H., et al. (2019). "Stem cell spheres for corneal regeneration," in Corneal Regeneration: Therapy and Surgery, eds J. L. Alió, J. L. Alió del Barrio, and F. Arnalich-Montiel (Cham: Springer International Publishing), 299-316.

Jangamreddy, J. R., Haagdorens, M. K. C., Islam, M., Lewis, P., Samanta, A., Fagerholm, P., et al. (2018). Short peptide analogs as alternatives to collagen in pro-regenerative corneal implants. Acta Biomater. 69, 120-130. doi: 10.1016/j.actbio.2018.01.011

Jeng, B. H., Farid, M., Patel, S. V., and Schwab, I. R. (2016). Corneal cross-linking for Keratoconus: a look at the data, the Food and Drug Administration, and the future. Ophthalmology 123, 2270-2272. doi: 10.1016/j.ophtha.2016.08.006

Jirásková, N., Rozsival, P., Burova, M., and Kalfertova, M. (2011). AlphaCor artificial cornea: clinical outcome. Eye 25, 1138-1146. doi: 10.1038/eye.2011.122

Kargozar, S., and Mozafari, M. (2018). Nanotechnology and nanomedicine: start small, think big. Mater. Today Proc. 5, 15492-15500. doi: 10.1016/j.matpr.2018.04.155

Karimi, M., Bahrami, S., Ravari, S. B., Zangabad, P. S., Mirshekari, H., Bozorgomid, M., et al. (2016a). Albumin nanostructures as advanced drug delivery systems. Expert Opin. Drug Delivery 13, 1609-1623. doi: 10.1080/17425247.2016.1193149

Karimi, M., Ghasemi, A., Zangabad, P., Rahighi, R., Basri, S. M., Mirshekari, H., et al. (2016b). Smart micro/nanoparticles in stimulus-responsive drug/gene delivery systems. Chem. Soc. Rev. 45, 1457-1501. doi: 10.1039/C5CS 00798D

Karimi, M., Mirshekari, H., Aliakbari, M., Sahandi-Zangabad, P., and Hamblin, M. R. (2016c). Smart mesoporous silica nanoparticles for controlled-release drug delivery. Nanotechnol. Rev. 5, 195-207. doi: 10.1515/ntrev-2015-0057
Karimi, M., Solati, N., Amiri, M., Mirshekari, H., Mohamed, E., Taheri, M., et al. (2015a). Carbon nanotubes part I: preparation of a novel and versatile drug-delivery vehicle. Expert Opin. Drug Delivery 12, 1071-1087. doi: $10.1517 / 17425247.2015 .1003806$

Karimi, M., Solati, N., Ghasemi, A., Estiar, M. A., Hashemkhani, M., Kiani, P., et al. (2015b). Carbon nanotubes part II: a remarkable carrier for drug and gene delivery. Expert Opin. Drug Delivery 12, 1089-1105. doi: 10.1517/17425247.2015.1004309

Katori, R., Hayashi, R., Kobayashi, Y., Kobayashi, E., and Nishida, K. (2016) Ebselen preserves tissue-engineered cell sheets and their stem cells in hypothermic conditions. Sci. Rep. 6:38987. doi: 10.1038/srep38987

Kaufman, P. L., Levin, L. A., Adler, F. H., and Alm, A. (2011). Adler's Physiology of the Eye. Amsterdam: Elsevier Health Sciences.

Khadem, J., Martino, M., Anatelli, F., Dana, M. R., and Hamblin, M. R. (2004). Healing of perforating rat corneal incisions closed with photodynamic laseractivated tissue glue. Lasers Surg. Med. 35, 304-311. doi: 10.1002/lsm.20099

Khadem, J., Tsao, K., Hamblin, M., Goslee, M., Tolentino, F., and Dana, M. (2000). "Photodynamic biologic tissue glue in perforating rabbit corneal wounds," in Investigative Ophthalmology and Visual Science (Bethesda, MD: Assoc Research Vision Ophthalmology Inc.), S700-S700.

Kim, E. Y., Tripathy, N., Cho, S. A., Lee, D., and Khang, G. (2017a). Collagen type I-PLGA film as an efficient substratum for corneal endothelial cells regeneration. J. Tissue Eng. Regenerat. Med. 11, 2471-2478. doi: 10.1002/term.2145

Kim, J. W., Jeong, H., Yang, M. S., Lim, C. W., and Kim, B. (2017b). Therapeutic effects of zerumbone in an alkali-burned corneal wound healing model. Int. Immunopharmacol. 48, 126-134. doi: 10.1016/j.intimp.2017.05.005

Kim, M. K., Park, I. S., Dal Park, H., Wee, W. R., Lee, J. H., Park, K. D., et al. (2001). Effect of poly (ethylene glycol) graft polymerization of poly (methyl methacrylate) on cell adhesion: in vitro and in vivo study. J. Cataract Refract. Surg. 27, 766-774. doi: 10.1016/S0886-3350(00)00701-X

Kobayashi, T., Kan, K., Nishida, K., Yamato, M., and Okano, T. (2013). Corneal regeneration by transplantation of corneal epithelial cell sheets fabricated with automated cell culture system in rabbit model. Biomaterials 34, 9010-9017. doi: 10.1016/j.biomaterials.2013.07.065

Koizumi, N., and Okumura, N. (2019). "Cell based therapy for corneal endothelial regeneration," in Corneal Regeneration: Therapy and Surgery, eds J. L. Alió, J. L. Alió del Barrio, and F. Arnalich-Montiel (Cham: Springer International Publishing), 455-462.

Kong, B., Sun, W., Chen, G., Tang, S., Li, M., Shao, Z., et al. (2017). Tissueengineered cornea constructed with compressed collagen and laser-perforated electrospun mat. Sci. Rep. 7:970. doi: 10.1038/s41598-017-01072-0

Kowalski, K. (2016). "Plastic that mimics insect wings kills bacteria the curved plastic may one day be used as an artificial cornea," in ScienceNewsforStudents. Available online at: https://www.sciencenewsforstudents.org/article/plasticmimics-insect-wings-kills-bacteria

Laattala, K., Huhtinen, R., Puska, M., Arstila, H., Hupa, L., Kellomäki, M., et al. (2011). Bioactive composite for keratoprosthesis skirt. J. Mech. Behav. Biomed. Mater. 4, 1700-1708. doi: 10.1016/j.jmbbm.2011.05.025

Lagali, N., Edén, U., Utheim, T. P., Chen, X., Riise, R., Dellby, A., et al. (2013) In vivo morphology of the limbal palisades of vogt correlates with progressive stem cell deficiency in aniridia-related keratopathy. Invest. Ophthalmol. Visual Sci. 54, 5333-5342. doi: 10.1167/iovs.13-11780

Lai, J. Y., and Ma, D. H. (2017). Ocular biocompatibility of gelatin microcarriers functionalized with oxidized hyaluronic acid. Mater. Sci. Eng. C 72, 150-159. doi: 10.1016/j.msec.2016.11.067

Lawrence, B. D., Marchant, J. K., Pindrus, M. A., Omenetto, F. G., and Kaplan, D. L. (2009). Silk film biomaterials for cornea tissue engineering. Biomaterials 30, 1299-1308. doi: 10.1016/j.biomaterials.2008.11.018

Lee, R., Khoueir, Z., Tsikata, E., Chodosh, J., Dohlman, C. H., and Chen, T. C. (2017). Long-term visual outcomes and complications of Boston keratoprosthesis type II implantation. Ophthalmology 124, 27-35. doi: 10.1016/j.ophtha.2016.07.011

Levis, H. J., and Daniels, J. T. (2016). Recreating the human limbal epithelial stem cell niche with bioengineered limbal crypts. Curr. Eye Res. 41, 1153-1160. doi: 10.3109/02713683.2015.1095932

Levis, H. J., Massie, I., Dziasko, M. A., Kaasi, A., and Daniels, J. T. (2013). Rapid tissue engineering of biomimetic human corneal 
limbal crypts with 3D niche architecture. Biomaterials 34, 8860-8868. doi: 10.1016/j.biomaterials.2013.08.002

Lih, E., Lee, J. S., Park, K. M., and Park, K. D. (2012). Rapidly curable chitosan-PEG hydrogels as tissue adhesives for hemostasis and wound healing. Acta Biomater. 8, 3261-3269. doi: 10.1016/j.actbio.2012.05.001

Lin, Y.-K., Sharma, R., Ma, H., Chen, W.-S., and Yao, C.-L. (2017). In situ polymerizable hydrogel incorporated with specific pathogen-free porcine platelet-rich plasma for the reconstruction of the corneal endothelium. J. Taiwan Institute Chem. Eng. 78, 65-74. doi: 10.1016/j.jtice.2017.06.006

Liu, J., Lawrence, B. D., Liu, A., Schwab, I. R., Oliveira, L. A., and Rosenblatt, M. I. (2012). Silk fibroin as a biomaterial substrate for corneal epithelial cell sheet generation. Invest. Ophthalmol. Visual Sci. 53, 4130-4138. doi: 10.1167/iovs.12-9876

Long, Y., Zhao, X., Liu, S., Chen, M., Liu, B., Ge, J., et al. (2018). Collagenhydroxypropyl methylcellulose membranes for corneal regeneration. ACS Omega 3, 1269-1275. doi: 10.1021/acsomega.7b01511

Ludwig, P. E., Huff, T. J., and Zuniga, J. M. (2018). The potential role of bioengineering and three-dimensional printing in curing global corneal blindness. J. Tissue Eng. 9:2041731418769863. doi: 10.1177/2041731418769863

Luo, L. J., Lai, J. Y., Chou, S. F., Hsueh, Y. J., and Ma, D. H. (2018). Development of gelatin/ascorbic acid cryogels for potential use in corneal stromal tissue engineering. Acta Biomater. 65, 123-136. doi: 10.1016/j.actbio.2017.11.018

Lužnik, Z., Breda, C., Barbaro, V., Ferrari, S., Migliorati, A., Di Iorio, E., et al. (2017). Towards xeno-free cultures of human limbal stem cells for ocular surface reconstruction. Cell Tissue Banking 18, 461-474. doi: 10.1007/s10561-017-9632-7

Ma, X., Xiang, R., Meng, X., Qin, L., Wu, Y., Tain, L., et al. (2017). Russian keratoprosthesis in stevens-johnson syndrome. Cornea 36, 304-309. doi: 10.1097/ICO.0000000000001094

Mannis, M. J., and Mannis, A. A. (1999). Corneal Transplantation: A History in Profiles. Oostende: JP Wayenborgh.

Manolova, Y., Stoycheva, Z., Yordanov, Y., and Grupcheva, C. (2017). Amniotic membrane transplantation-Analysis of structural characteristics in amniotic membrane transplant and corneal ulcers. Scripta Sci. Med. 49, 12-20. doi: 10.14748/ssm.v49i1.2060

Massie, I., Levis, H. J., and Daniels, J. T. (2014). Response of human limbal epithelial cells to wounding on 3D RAFT tissue equivalents: effect of airlifting and human limbal fibroblasts. Exp. Eye Res. 127, 196-205. doi: 10.1016/j.exer.2014.07.024

Matthyssen, S., Van den Bogerd, B., Dhubhghaill, S. N., Koppen, C., and Zakaria, N. (2018). Corneal regeneration: a review of stromal replacements. Acta Biomater. 69, 31-41. doi: 10.1016/j.actbio.2018.01.023

Maurice, D. M. (1957). The structure and transparency of the cornea. J. Physiol. 136, 263-286. doi: 10.1113/jphysiol.1957.sp005758

Meek, K. M., and Knupp, C. (2015). Corneal structure and transparency. Prog. Retinal Eye Res. 49, 1-16. doi: 10.1016/j.preteyeres.2015.07.001

Miller, D., and Benedek, G. (1973). Intraocular Light Scattering: Theory and Clinical Application. Charles City, IA: Thomas Publisher. doi: 10.1097/00006324-197312000-00019

Mohammadi, M. R., Nojoomi, A., Mozafari, M., Dubnika, A., Inayathullah, M., and Rajadas, J. (2017). Nanomaterials engineering for drug delivery: a hybridization approach. J. Mater. Chem. B 5, 3995-4018. doi: 10.1039/C6TB03247H

Mozafari, M. (2014). The critical impact of controlled drug delivery in the future of tissue engineering. Trends Biomater. Artif. Organs 28, 124-126. Available online at: https://web.a.ebscohost.com/ abstract ?direct $=$ true \&profile $=$ ehost $\&$ scope $=$ site \&authtype $=$ crawler \&jrnl $=097$ 11198\&AN=111415494\&h=Lx8yPqvR3v22gqn82gz3O\%2fxlskO6fvyL9LRiTD XlHKpjDUKnuEk10FiOvQRFUcEbstQSYWjQmaXS9NxGA93QbA\%3d\%3d\& $\mathrm{crl}=\mathrm{c} \&$ resultNs $=$ AdminWebAuth\&resultLocal=ErrCrlNotAuth\&crlhashurl $=$ login.aspx\%3fdirect\%3dtrue $\% 26$ profile\%3dehost $\% 26$ scope $\% 3$ dsite $\% 26$ auth type\%3dcrawler\%26jrnl\%3d09711198\%26AN\%3d111415494

Mozafari, M., Rajadas, J., and Kaplan, D. (2019). Nanoengineered Biomaterials for Regenerative Medicine. Amsterdam: Elsevier. doi: 10.1016/B978-0-12-813355-2.00001-6

Muijzer, M. B., van Luijk, C. M., van den Bogaerdt, A. J., Kruit, P. J., Groeneveld-van Beek, E., Melles, G. R. J., et al. (2019). Prospective evaluation of clinical outcomes between pre-cut corneal grafts prepared using a manual or automated technique: with one-year follow-up. Acta Ophthalmol. doi: 10.1111/aos.14074. [Epub ahead of print].

Nagai, N., Nakazawa, Y., Ito, Y., Kanai, K., Okamoto, N., and Shimomura, Y. (2017). A nanoparticle-based ophthalmic formulation of dexamethasone enhances corneal permeability of the drug and prolongs its corneal residence time. Biol. Pharma. Bull. 40, 1055-1062. doi: 10.1248/bpb.b17-00137

Nakajima, R., Kobayashi, T., Moriya, N., Mizutani, M., Kan, K., Nozaki, T., et al. (2015). A novel closed cell culture device for fabrication of corneal epithelial cell sheets. J. Tissue Eng. Regenerat. Med. 9, 1259-1267. doi: 10.1002/term.1639

Nakamura, T., Inatomi, T., Sotozono, C., Koizumi, N., and Kinoshita, S. (2016). Ocular surface reconstruction using stem cell and tissue engineering. Prog. Retinal Eye Res. 51, 187-207. doi: 10.1016/j.preteyeres.2015.07.003

Neuman, M. G., Nanau, R. M., Oruña-Sanchez, L., and Coto, G. (2015). Hyaluronic acid and wound healing. J. Pharmacy Pharma. Sci. 18, 53-60. doi: $10.18433 / \mathrm{JK} 89 \mathrm{D}$

Nishida, K., Yamato, M., Hayashida, Y., Watanabe, K., Maeda, N., Watanabe, H., et al. (2004a). Functional bioengineered corneal epithelial sheet grafts from corneal stem cells expanded ex vivo on a temperature-responsive cell culture surface. Transplantation 77, 379-385. doi: 10.1097/01.TP.0000110320.45678.30

Nishida, K., Yamato, M., Hayashida, Y., Watanabe, K., Yamamoto, K., Adachi, E., et al. (2004b). Corneal reconstruction with tissue-engineered cell sheets composed of autologous oral mucosal epithelium. N. Engl. J. Med. 351, 1187-1196. doi: 10.1056/NEJMoa040455

Ogawa, Y., He, H., Mukai, S., Imada, T., Nakamura, S., Su, C. W., et al. (2017). Heavy chain-hyaluronan/pentraxin 3 from amniotic membrane suppresses inflammation and scarring in murine lacrimal gland and conjunctiva of chronic graft-versus-host disease. Sci. Rep. 7:42195. doi: 10.1038/srep42195

Omoto, M., Suri, K., Amouzegar, A., Li, M., Katikireddy, K. R., Mittal, S. K., et al. (2017). Hepatocyte growth factor suppresses inflammation and promotes epithelium repair in corneal injury. Mol. Ther. 25, 1881-1888. doi: 10.1016/j.ymthe.2017.04.020

Ortega, I., Deshpande, P., Gill, A. A., MacNeil, S., and Claeyssens, F. (2013a). Development of a microfabricated artificial limbus with micropockets for cell delivery to the cornea. Biofabrication 5:025008. doi: 10.1088/1758-5082/5/2/025008

Ortega, I., McKean, R., Ryan, A. J., MacNeil, S., and Claeyssens, F. (2014a). Characterisation and evaluation of the impact of microfabricated pockets on the performance of limbal epithelial stem cells in biodegradable PLGA membranes for corneal regeneration. Biomater. Sci. 2, 723-734. doi: 10.1039/C3BM60268K

Ortega, I., Ryan, A., MacNeil, S., and Claeyssens, F. (2012). Development of tissue engineered stem cell niches for corneal repair", in Journal of Tissue Engineering and Regenerative Medicine (Hoboken, NJ: Wiley-Blackwell), 137-137.

Ortega, I., Ryan, A. J., Deshpande, P., MacNeil, S., and Claeyssens, F. (2013b). Combined microfabrication and electrospinning to produce 3-D architectures for corneal repair. Acta Biomater. 9, 5511-5520. doi: 10.1016/j.actbio.2012.10.039

Ortega, I., Sefat, F., Deshpande, P., Paterson, T., Ramachandran, C., Ryan, A. J., et al. (2014b). Combination of microstereolithography and electrospinning to produce membranes equipped with niches for corneal regeneration. J. Visual. Exp. 91:51826. doi: 10.3791/51826

Oryan, A., and Sahvieh, S. (2017). Effectiveness of chitosan scaffold in skin, bone and cartilage healing. Int. J. Biol. Macromolecules 104, 1003-1011. doi: 10.1016/j.ijbiomac.2017.06.124

Owaki, T., Shimizu, T., Yamato, M., and Okano, T. (2014). Cell sheet engineering for regenerative medicine: current challenges and strategies. Biotechnol. J. 9, 904-914. doi: 10.1002/biot.201300432

Pandey, A., Prasad, A., Moscatello, J. P., and Yap, Y. K. (2010). Stable electron field emission from PMMA- CNT Matrices. Acs Nano 4, 6760-6766. doi: $10.1021 / \mathrm{nn} 100925 \mathrm{~g}$

Patel, S., Thakar, R. G., Wong, J., McLeod, S. D., and Li, S. (2006). Control of cell adhesion on poly (methyl methacrylate). Biomaterials 27, 2890-2897. doi: 10.1016/j.biomaterials.2005.12.009

Pellegrini, G., Ranno, R., Stracuzzi, G., Bondanza, S., Guerra, L., Zambruno, G., et al. (1999). The control of epidermal stem cells (holoclones) in the treatment of massive full-thickness burns with autologous keratinocytes cultured on fibrin1. Transplantation 68, 868-879. doi: 10.1097/00007890-19990927000021 
Pineda, R. (2015). "The keraklear artificial cornea," in Keratoprostheses and Artificial Corneas, eds M. Cortina and J. de la Cruz (New York, NY: Springer), 213-219. doi: 10.1007/978-3-642-55179-6_23

Pino, M., Stingelin, N., and Tanner, K. E. (2008). Nucleation and growth of apatite on NaOH-treated PEEK, HDPE and UHMWPE for artificial cornea materials. Acta Biomater. 4, 1827-1836. doi: 10.1016/j.actbio.2008.05.004

Polisetti, N., McLaughlin, C. R., Vemuganti, G. K., and Griffith, M. (2013). "Biomaterials-enabled regenerative medicine in corneal applications," in Regenerative Medicine: From Protocol to Patient, ed G. Steinhoff. (Dordrecht: Springer Netherlands), 557-580. doi: 10.1007/978-94-007-5690-8_22

Prabhasawat, P. (2017). Amniotic membrane: a treatment for prevention of blindness from various ocular diseases. Siriraj Med. J. 59, 139-141. Available online at: http://www.smj.si.mahidol.ac.th/sirirajmedj/index.php/smj/article/ viewFile/641/653

Prina, E., Mistry, P., Sidney, L. E., Yang, J., Wildman, R. D., Bertolin, M., et al. (2017). 3D microfabricated scaffolds and microfluidic devices for ocular surface replacement: a review. Stem Cell Rev. Rep. 13, 430-441. doi: 10.1007/s12015-017-9740-6

Quantock, A. J., Winkler, M., Parfitt, G. J., Young, R. D., Brown, D. J., Boote, C., et al. (2015). From nano to macro: studying the hierarchical structure of the corneal extracellular matrix. Exp. Eye Res. 133, 81-99. doi: $10.1016 /$ j.exer.2014.07.018

Rahman, H. S., Rasedee, A., Yeap, S. K., Othman, H. H., Chartrand, M. S., Namvar, F., et al. (2014). Biomedical properties of a natural dietary plant metabolite, zerumbone, in cancer therapy and chemoprevention trials. BioMed Res. Int. 2014:920742. doi: 10.1155/2014/920742

Rahmati, M., and Mozafari, M. (2018). Protein adsorption on polymers. Mater. Today Commun. 17, 527-540. doi: 10.1016/j.mtcomm.2018.10.024

Rahmati, M., and Mozafari, M. (2019a). Biological response to carbon-family nanomaterials: interactions at the nano-bio interface. Front. Bioeng. Biotechnol. 7:4. doi: 10.3389/fbioe.2019.00004

Rahmati, M., and Mozafari, M. (2019b). Nano-immunoengineering: opportunities and challenges. Curr. Opin. Biomed. Eng. 10, 51-59. doi: 10.1016/j.cobme.2019.02.001

Rahmati, M., Pennisi, C. P., Mobasheri, A., and Mozafari, M. (2018). Bioengineered scaffolds for stem cell applications in tissue engineering and regenerative medicine. Adv. Exp. Med. Biol. 1107, 73-89. doi: 10.1007/5584_2018_215

Rajendran, V., Netuková, M., Griffith, M., Forrester, J. V., and Kuffová, L. (2017). Mesenchymal stem cell therapy for retro-corneal membrane - a clinical challenge in full-thickness transplantation of biosynthetic corneal equivalents. Acta Biomater. 64, 346-356. doi: 10.1016/j.actbio.2017.10.011

Rama, P., Bonini, S., Lambiase, A., Golisano, O., Paterna, P., De Luca, M., et al. (2001). Autologous fibrin-cultured limbal stem cells permanently restore the corneal surface of patients with total limbal stem cell deficiencyl. Transplantation 72, 1478-1485. doi: 10.1097/00007890-200111150-00002

Rama, P., Matuska, S., Paganoni, G., Spinelli, A., De Luca, M., and Pellegrini, G. (2010). Limbal stem-cell therapy and long-term corneal regeneration. N. Engl. J. Med. 363, 147-155. doi: 10.1056/NEJMoa0905955

Ramachandran, C., Sangwan, V. S., Ortega, I., Bhatnagar, U., Mulla, S. M. A., McKean, R., et al. (2019). Synthetic biodegradable alternatives to the use of the amniotic membrane for corneal regeneration: assessment of local and systemic toxicity in rabbits. Br. J. Ophthalmol. 103, 286-292. doi: 10.1136/bjophthalmol-2018-312055

Reimondez-Troitiño, S., Alcalde, I., Csaba, N., Íñigo-Portugués, A., de la Fuente, M., Bech, F., et al. (2016). Polymeric nanocapsules: a potential new therapy for corneal wound healing. Drug Deliver. Trans. Res. 6, 708-721. doi: 10.1007/s13346-016-0312-0

Riau, A. K., Mondal, D., Setiawan, M., Palaniappan, A., Yam, G. H., Liedberg, B., et al. (2016). Functionalization of the polymeric surface with bioceramic nanoparticles via a novel, nonthermal dip coating method. ACS Appl. Mater. Interfaces 8, 35565-35577. doi: 10.1021/acsami.6b12371

Rizwan, M., Peh, G. S. L, Ang, H. P., Lwin, N. C., Adnan, K., Mehta, J. S., et al. (2017). Sequentially-crosslinked bioactive hydrogels as nanopatterned substrates with customizable stiffness and degradation for corneal tissue engineering applications. Biomaterials 120, 139-154. doi: 10.1016/j.biomaterials.2016.12.026
Robciuc, A., Arvola, R. P. J., Jauhiainen, M., and Holopainen, J. M. (2018). Matrix regeneration agents improve wound healing in non-stressed human corneal epithelial cells. Eye 32:813. doi: 10.1038/eye.2017.277

Ronfard, V., Broly, H., Mitchell, V., Galizia, J. P., Hochart, D., Chambon, E., et al. (1991). Use of human keratinocytes cultured on fibrin glue in the treatment of burn wounds. Burns 17, 181-184. doi: 10.1016/0305-4179(91) 90099-3

Ronfard, V., Rives, J.-M., Neveux, Y., Carsin, H., and Barrandon, Y. (2000). Longterm regeneration of human epidermis on third degree burns transplanted with autologous cultured epithelium grown on a fibrin matrix1, 2. Transplantation 70, 1588-1598. doi: 10.1097/00007890-200012150-00009

Sabater, A. L., and Perez, V. L. (2017). Amniotic membrane use for management of corneal limbal stem cell deficiency. Curr. Opin. Ophthalmol. 28, 363-369. doi: 10.1097/ICU.0000000000000386

Saghizadeh, M., Kramerov, A. A., Svendsen, C. N., and Ljubimov, A. V. (2017). Concise review: stem cells for corneal wound healing. Stem Cells 35, 2105-2114. doi: $10.1002 /$ stem. 2667

Salehi, S., Czugala, M., Stafiej, P., Fathi, M., Bahners, T., Gutmann, J. S., et al. (2017). Poly (glycerol sebacate)-poly ( $\varepsilon$-caprolactone) blend nanofibrous scaffold as intrinsic bio-and immunocompatible system for corneal repair. Acta Biomater. 50, 370-380. doi: 10.1016/j.actbio.2017.01.013

Salvador-Culla, B., Jeong, K. J., Kolovou, P. E., Chiang, H. H., Chodosh, J., Dohlman, C. H., et al. (2016). Titanium coating of the Boston keratoprosthesis. Trans. Vis. Sci. Technol. 5:17. doi: 10.1167/tvst.5.2.17

Sasamoto, Y., Ksander, B. R., Frank, M. H., and Frank, N. Y. (2018). Repairing the corneal epithelium using limbal stem cells or alternative cell-based therapies. Expert Opin. Biol. Ther. 18, 505-513. doi: 10.1080/14712598.2018.1443442

Schmidl, D., Werkmeister, R., Kaya, S., Unterhuber, A., Witkowska, K. J., Baumgartner, R., et al. (2017). A controlled, randomized double-blind study to evaluate the safety and efficacy of chitosan-N-acetylcysteine for the treatment of dry eye syndrome. J. Ocular Pharmacol. Ther. 33, 375-382. doi: 10.1089/jop.2016.0123

Schrader, S., Wedel, T., Moll, R., and Geerling, G. (2006). Combination of serum eye drops with hydrogel bandage contact lenses in the treatment of persistent epithelial defects. Graefe's Arch. Clin. Exp. Ophthalmol. 244, 1345-1349. doi: 10.1007/s00417-006-0257-y

Schrage, N., Hille, K., and Cursiefen, C. (2014). Current treatment options with artificial corneas: boston Kpro, Osteo-odontokeratoprosthesis, Miro Cornea ${ }^{\circledR}$ and $\operatorname{KeraKlear}^{\circledR}$. Der Ophthalmol. 111, 1010-1018. doi: 10.1007/s00347-013-3009-5

Schroder, K., and Tschopp, J. (2010). The inflammasomes. Cell 140, 821-832. doi: $10.1016 /$ j.cell.2010.01.040

Sigroha, S., and Khatkar, A. (2017). Chitosan-A naturally derived antioxidant polymer with diverse applications. Curr. Organic Chem. 21, 333-341. doi: 10.2174/1385272820666161018130542

Simpson, F., Alarcon, E. I., Hilborn, J., Brunette, I., and Griffith, M. (2019). "Regenerative medicine in the cornea," in Principles of Regenerative Medicine, eds A. Atala, R. Lanza, T. Mikos, and R. Nerem (Amsterdam: Elsevier), 1115-1129. doi: 10.1016/B978-0-12-809880-6.00063-1

Soleimanifar, F., Mortazavi, Y., Nadri, S., and Soleimani, M. (2017). Conjunctiva derived mesenchymal stem cell (CJMSCs) as a potential platform for differentiation into corneal epithelial cells on bioengineered electrospun scaffolds. J. Biomed. Mater. Res. A 105, 2703-2711. doi: 10.1002/jbm.a.36123

Sommer, A. (1982). Nutritional Blindness. Xerophthalmia and Keratomalacia. New York, NY; Oxford University Press. doi: 10.1001/archopht.1982.01030030401002

Sorkio, A., Koch, L., Koivusalo, L., Deiwick, A., Miettinen, S., Chichkov, B., et al. (2018). Human stem cell based corneal tissue mimicking structures using laser-assisted 3D bioprinting and functional bioinks. Biomaterials 171, 57-71. doi: 10.1016/j.biomaterials.2018.04.034

Soumya, S., Mohamed, A. P., Paul, L., Mohan, K., and Ananthakumar, S. (2014). Near IR reflectance characteristics of PMMA/ZnO nanocomposites for solar thermal control interface films. Solar Energy Mater. Solar Cells 125, 102-112. doi: 10.1016/j.solmat.2014.02.033

Sriram, S., Tran, J. A., Guo, X., Hutcheon, A. E. K., Kazlauskas, A., and Zieske, J. D. (2017). development of wound healing models to study Tgf $\beta 3$ 's effect on Sma. Exp. Eye Res. 161, 52-60. doi: 10.1016/j.exer.2017.06.005 
St. Denis, T. G., Dai, T., Huang, Y. Y., and Hamblin, M. R. (2012). "Wound-healing properties of chitosan and its use in wound dressing biopharmaceuticals," in Chitosan-Based Systems for Biopharmaceuticals: Delivery, Targeting Polymer Therapeutics, eds B. Sarmento and J. das Neves, 429-450. doi: 10.1002/9781119962977.ch22. [Epub ahead of print].

Syed-Picard, F. N., Du, Y., Hertsenberg, A. J., Palchesko, R., Funderburgh, M. L., Feinberg, A. W., et al. (2018). Scaffold-free tissue engineering of functional corneal stromal tissue. J. Tissue Eng. Regenerat. Med. 12, 59-69. doi: 10.1002/term.2363

Takechi, Y., Tanaka, H., Kitayama, H., Yoshii, H., Tanaka, M., and Saito, H. (2012). Comparative study on the interaction of cell-penetrating polycationic polymers with lipid membranes. Chem. Phys. Lipids 165, 51-58. doi: 10.1016/j.chemphyslip.2011.11.002

Tan, X. W., Thompson, B., Konstantopoulos, A., Goh, T. W., Setiawan, M., Yam, G. H., et al. (2015). Application of graphene as candidate biomaterial for synthetic keratoprosthesis skirt. Invest. Ophthalmol. Visual Sci. 56, 6605-6611. doi: 10.1167/iovs.15-17306

Tang, Q., Luo, C., Lu, B., Fu, Q., Yin, H., Qin, Z., et al. (2017). Thermosensitive chitosan-based hydrogels releasing stromal cell derived factor-1 alpha recruit MSC for corneal epithelium regeneration. Acta Biomater. 61, 101-113. doi: 10.1016/j.actbio.2017.08.001

Tighe, S., Moein, H. R., Chua, L., Cheng, A., Hamrah, P., and Tseng, S. C. (2017). Topical cryopreserved amniotic membrane and umbilical cord eye drops promote re-epithelialization in a murine corneal abrasion model. Invest. Ophthalmol. Visual Sci. 58, 1586-1593. doi: 10.1167/iovs.16-20834

Tóth, E., Beyer, D., Zsebik, B., Vereb, G., and Takács, L. (2017). Limbal and conjunctival epithelial cell cultivation on contact lenses-different affixing techniques and the effect of feeder cells. Eye Contact Lens 43, 162-167. doi: 10.1097/ICL.0000000000000259

Tsai, C. Y., Woung, L. C., Yen, J. C., Tseng, P. C., Chiou, S. H., Sung, Y. J., et al. (2016). Thermosensitive chitosan-based hydrogels for sustained release of ferulic acid on corneal wound healing. Carbohydrate Polymers 135, 308-315. doi: 10.1016/j.carbpol.2015.08.098

Vázquez, N., Rodríguez-Barrientos, C. A., Aznar-Cervantes, S. D., Chacón, M., Cenis, J. L., Riestra, A. C., et al. (2017). Silk fibroin films for corneal endothelial regeneration: transplant in a rabbit descemet membrane endothelial keratoplasty. Invest. Ophthalmol. Visual Sci. 58, 3357-3365. doi: 10.1167/iovs.17-21797

Vepari, C., and Kaplan, D. L. (2007). Silk as a biomaterial. Prog. Polymer Sci. 32, 991-1007. doi: 10.1016/j.progpolymsci.2007.05.013

Wang, L., Huang, Y., Du, G., Dong, Y., Guo, H., Wang, D., et al. (2015). Longterm outcomes and complications of Moscow Eye Microsurgery Complex in Russia (MICOF) keratoprosthesis following ocular surface burns: clinical experience in China. Br. J. Ophthalmol. 99:12. doi: 10.1136/bjophthalmol-2014306115

Wang, W. Y., Lee, Y. K., Tsai, S. H., Lin, Y. C., and Chen, Y. M. (2017). Autologous serum eye drops combined with silicone hydrogen lenses for the treatment of postinfectious corneal persistent epithelial defects. Eye Contact Lens 43, 225-229. doi: 10.1097/ICL.0000000000000261

Weisshuhn, K., Berg, I., Tinner, D., Kunz, C., Bornstein, M. M., Steineck, M., et al. (2014). Osteo-odonto-keratoprosthesis (OOKP) and the testing of three different adhesives for bonding bovine teeth with optical poly(methyl methacrylate)(PMMA) cylinder. Br. J. Ophthalmol. 98, 980-983. doi: 10.1136/bjophthalmol-2013-303141

Weng, Y., Liu, J., Jin, S., Guo, W., Liang, X., and Hu, Z. (2017). Nanotechnologybased strategies for treatment of ocular disease. Acta Pharma. Sin. B 7, 281-291. doi: 10.1016/j.apsb.2016.09.001

Werkmeister, R. M., Sapeta, S., Schmidl, D., Garhöfer, G., Schmidinger, G., dos Santos, V., et al. (2017). Ultrahigh-resolution OCT imaging of the human cornea. Biomed. Optics Express 8, 1221-1239. doi: 10.1364/BOE.8. 001221

Westekemper, H., Figueiredo, F. C., Siah, W. F., Wagner, N., Steuhl, K. P., and Meller, D. (2017). Clinical outcomes of amniotic membrane transplantation in the management of acute ocular chemical injury. Br. J. Ophthalmol. 101, 103-107. doi: 10.1136/bjophthalmol-2015-308037

Whitcher, J. P., Srinivasan, M., and Upadhyay, M. P. (2001). Corneal blindness: a global perspective. Bull. World Health Organ. 79, 214-221. Available online at: http://www.who.int/iris/handle/10665/58078
Wicklein, V. J., Singer, B. B., Scheibel, T., and Salehi, S. (2019). "Nanoengineered biomaterials for corneal regeneration," in Nanoengineered Biomaterials for Regenerative Medicine, eds M. Mozafari, J. Rajadas, and D. Kaplan (Amsterdam: Elsevier), 379-415. doi: 10.1016/B978-0-12-813355-2.00017-X

Wijnholds, J. (2019). "Basal cell migration" in regeneration of the corneal woundbed. Stem Cell Rep. 12, 3-5. doi: 10.1016/j.stemcr.2018.12.009

Wu, M. F., Stachon, T., Langenbucher, A., Seitz, B., and Szentmáry, N. (2017). Effect of amniotic membrane suspension (AMS) and amniotic membrane homogenate (AMH) on human corneal epithelial cell viability, migration and proliferation in vitro. Curr. Eye Res. 42, 351-357. doi: 10.1080/02713683.2016.1192193

Xie, R. Z., Sweeney, D. F., Beumer, G. J., Johnson, G., Griesser, H. J., and Steele, J. G. (1997). Effects of biologically modified surfaces of synthetic lenticules on corneal epithelialization in vivo. Austr. N. Zeal. J. Ophthalmol. 25, 46-49. doi: 10.1111/j.1442-9071.1997.tb01755.x

Yam, G. H., Teo, E. P., Setiawan, M., Lovatt, M. J., Yusoff, N. Z. B. M., Fuest, M., et al. (2018). Postnatal periodontal ligament as a novel adult stem cell source for regenerative corneal cell therapy. J. Cell. Mol. Med. 22, 3119-3132. doi: $10.1111 /$ jcmm.13589

Yamashita, K., Inagaki, E., Hatou, S., Higa, K., Ogawa, A., Miyashita, H., et al. (2018). Corneal endothelial regeneration using mesenchymal stem cell derived from human umbilical cord. Stem Cells Dev. 27:16. doi: 10.1089/scd.2017.0297

Zakaria, N., Possemiers, T., Dhubhghaill, S. N., Leysen, I., Rozema, J., Koppen, C., et al. (2014). Results of a phase I/II clinical trial: standardized, nonxenogenic, cultivated limbal stem cell transplantation. J. Trans. Med. 12:58. doi: 10.1186/1479-5876-12-58

Zarrintaj, P., Ahmadi, Z., Saeb, M. R., and Mozafari, M. (2018a). Poloxamerbased stimuli-responsive biomaterials. Mater. Today Proc. 5, 15516-15523. doi: 10.1016/j.matpr.2018.04.158

Zarrintaj, P., Bakhshandeh, B., Saeb, M. R., Sefat, F., Rezaeian, I., Ganjali, M. R., et al. (2018b). Oligoaniline-based conductive biomaterials for tissue engineering. Acta Biomater. 27, 16-34. doi: 10.1016/j.actbio.2018.03.042

Zarrintaj, P., Manouchehri, S., Ahmadi, Z., Saeb, M. R., Urbanska, A. M., Kaplan, D. L., et al. (2018c). Agarose-based biomaterials for tissue engineering. Carbohydrate Polymers 187, 66-84. doi: 10.1016/j.carbpol.2018.01.060

Zarrintaj, P., Moghaddam, A. S., Manouchehri, S., Atoufi, Z., Amiri, A., Amirkhani, M. A., et al. (2017). Can regenerative medicine and nanotechnology combine to heal wounds? The search for the ideal wound dressing. Nanomedicine 12, 2403-2422. doi: 10.2217/nnm-2017-0173

Zarrintaj, P., Saeb, M. R., Ramakrishna, S., and Mozafari, M. (2018d). Biomaterials selection for neuroprosthetics. Curr. Opin. Biomed. Eng. 6, 99-109. doi: 10.1016/j.cobme.2018.05.003

Zhang, L., Zou, D., Li, S., Wang, J., Qu, Y., Ou, S., et al. (2016). An ultra-thin amniotic membrane as carrier in corneal epithelium tissue-engineering. Sci. Rep. 6:21021. doi: 10.1038/srep21021

Zheng, T., and Xu, J. (2008). Age-related changes of human limbus on in vivo confocal microscopy. Cornea 27, 782-786. doi: 10.1097/ICO.0b013e31816f5ec3

Zhong, J., Deng, Y., Tian, B., Wang, B., Sun, Y., Huang, H., et al. (2016). Hyaluronate acid-dependent protection and enhanced corneal wound healing against oxidative damage in corneal epithelial cells. J. Ophthalmol. 2016:6538051. doi: 10.1155/2016/6538051

Zirm, E. K. (1989). Eine erfolgreiche totale Keratoplastik (A successful total keratoplasty). J. Refract. Surg. 5, 258-261.

Zsebik, B., Ujlaky-Nagy, L., Losonczy, G., Vereb, G., and Takács, L. (2017). Cultivation of human oral mucosal explants on contact lenses. Curr. Eye Res. 42, 1094-1099. doi: 10.1080/02713683.2017.1279635

Conflict of Interest Statement: The authors declare that the research was conducted in the absence of any commercial or financial relationships that could be construed as a potential conflict of interest.

Copyright (C) 2019 Mobaraki, Abbasi, Omidian Vandchali, Ghaffari, Moztarzadeh and Mozafari. This is an open-access article distributed under the terms of the Creative Commons Attribution License (CC BY). The use, distribution or reproduction in other forums is permitted, provided the original author(s) and the copyright owner(s) are credited and that the original publication in this journal is cited, in accordance with accepted academic practice. No use, distribution or reproduction is permitted which does not comply with these terms. 